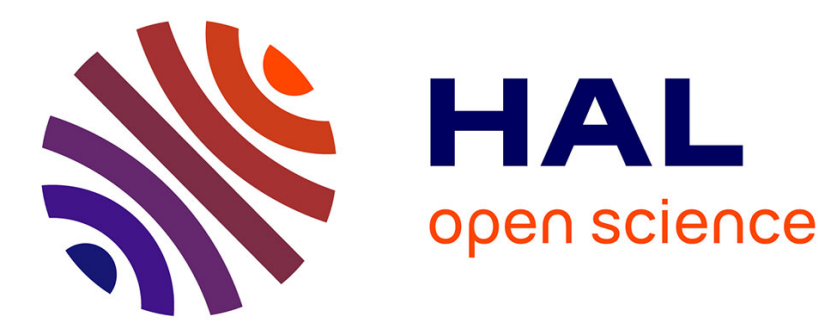

\title{
Cloud condensation nuclei activity at Jeju Island, Korea in spring 2005
}

\author{
M. Kuwata, Y. Kondo, Y. Miyazaki, Y. Komazaki, J. H. Kim, S. S. Yum, H. \\ Tanimoto, H. Matsueda
}

\section{- To cite this version:}

M. Kuwata, Y. Kondo, Y. Miyazaki, Y. Komazaki, J. H. Kim, et al.. Cloud condensation nuclei activity at Jeju Island, Korea in spring 2005. Atmospheric Chemistry and Physics, 2008, 8 (11), pp.2933-2948. hal-00296568

\section{HAL Id: hal-00296568 \\ https://hal.science/hal-00296568}

Submitted on 11 Jun 2008

HAL is a multi-disciplinary open access archive for the deposit and dissemination of scientific research documents, whether they are published or not. The documents may come from teaching and research institutions in France or abroad, or from public or private research centers.
L'archive ouverte pluridisciplinaire HAL, est destinée au dépôt et à la diffusion de documents scientifiques de niveau recherche, publiés ou non, émanant des établissements d'enseignement et de recherche français ou étrangers, des laboratoires publics ou privés. 


\title{
Cloud condensation nuclei activity at Jeju Island, Korea in spring 2005
}

\author{
M. Kuwata ${ }^{1}$, Y. Kondo ${ }^{1}$, Y. Miyazaki ${ }^{1,}$, Y. Komazaki ${ }^{1}$, J. H. Kim ${ }^{2}$, S. S. Yum ${ }^{2}$, H. Tanimoto ${ }^{3}$, and H. Matsueda ${ }^{4}$ \\ ${ }^{1}$ Research Center for Advanced Science and Technology, the University of Tokyo, Tokyo, Japan \\ ${ }^{2}$ Department of Atmospheric Science, Yonsei University, Seoul, Korea \\ ${ }^{3}$ Atmospheric Environmental Division, National Institute for Environmental Studies, Tsukuba, Japan \\ ${ }^{4}$ Geochemical Research Department, Meteorological Research Institute, Tsukuba, Japan \\ *now at: Institute of Low Temperature Science, Hokkaido University, Japan
}

Received: 12 October 2007 - Published in Atmos. Chem. Phys. Discuss.: 13 November 2007

Revised: 14 May 2008 - Accepted: 14 May 2008 - Published: 11 June 2008

\begin{abstract}
We measured the number concentrations of cloud condensation nuclei $(\mathrm{CCN})$ and the size distributions of $\mathrm{CCN} / \mathrm{CN}$ (CN: condensation nuclei) ratios at supersaturations ( $S S \mathrm{~s}$ ) of $0.097,0.27,0.58$, and $0.97 \%$ at Jeju Island, Korea during March-April 2005. We made simultaneous measurements of aerosol inorganic ions, water-soluble organic carbon (WSOC), organic carbon (OC), and elemental carbon (EC) in $\mathrm{PM}_{2.5}$. The $\mathrm{CCN} / \mathrm{CN}$ ratios increased with increasing particle diameter, and the diameter at $\mathrm{CCN} / \mathrm{CN}=0.5$ was defined as $D_{50}$. $D_{50}$ represents the activation dry diameter of atmospheric particles. The average $D_{50}$ at $S S=0.097 \%$ and $0.97 \%$ was $136 \pm 17 \mathrm{~nm}$ and $31 \pm 3 \mathrm{~nm}$, respectively. The temporal variation of $D_{50}$ at $S S=0.097 \%$ was correlated with the mass fraction of water-soluble components (inorganic ions + WSOC), indicating that the temporal variation of CCN activity was mainly controlled by changes in the water-soluble components fraction. The critical dry diameter $\left(D_{\text {crit }}\right)$, which is the threshold dry diameter for CCN activation, was calculated from the observed aerosol chemical compositions by Köhler theory for comparison with $D_{50}$. The $D_{50}$ at $S S=0.097 \%$ was correlated $\left(r^{2}=0.48\right)$ with calculated $D_{\text {crit }}$, although $D_{\text {crit }}$ was larger than $D_{50}$ by $20-29 \%$ on average. The systematic difference between $D_{50}$ and $D_{\text {crit }}$ could be caused by the size dependence of the aerosol chemical compositions or surface tension lowering caused by the mixing of water-soluble organic compounds. This difference corresponds to a $27 \pm 14 \%$ uncertainty in the $\mathrm{CCN}$ number concentration estimated from the observed particle number size distribution.
\end{abstract}

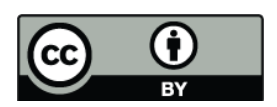

Correspondence to: Mikinori Kuwata (kuwata@atmos.rcast.u-tokyo.ac.jp)

\section{Introduction}

A subset of atmospheric particles acts as cloud condensation nuclei $(\mathrm{CCN})$. An increase in $\mathrm{CCN}$ number concentration causes an increase in cloud droplet concentration and a decrease in droplet size, which in turn impacts cloud albedo and precipitation. Consequently, CCN can significantly influence climate through cloud processes (Twomey, 1974; Lohmann and Feichter, 2005, and references therein).

The number concentration of $\mathrm{CCN}$ is determined by the number concentration of aerosol particles and the fraction of $\mathrm{CCN}$ active particles. This fraction is often denoted as the $\mathrm{CCN} / \mathrm{CN}$ ratio because condensation nuclei $(\mathrm{CN})$ counters have been used for total particle number concentration measurements (Seinfeld and Pandis, 2006). CCN/CN strongly depends on the size and chemical composition of aerosols. The influence of aerosol chemical composition and number size distribution on the bulk (size-unresolved) $\mathrm{CCN} / \mathrm{CN}$ can be separated by measuring $\mathrm{CCN} / \mathrm{CN}$ for size-selected particles. In particular, when aerosol particles are internally mixed, we can determine the threshold diameter from the measurements (Dusek et al., 2006). The threshold diameter can also be calculated by Köhler theory. Many laboratory studies have measured CCN/CN ratios of size-selected particles for comparison with theoretical calculations (e.g. Corrigan and Novakov, 1999; Raymond and Pandis, 2002). These experiments have shown that size-resolved $\mathrm{CCN} / \mathrm{CN}$ ratios of laboratory-generated particles can be explained by Köhler theory. However, only a few studies have employed this measurement method for atmospheric observations (e.g. Dusek et al., 2006), leading to an insufficient understanding of controlling factors for the $\mathrm{CCN}$ activation of atmospheric particles.

Published by Copernicus Publications on behalf of the European Geosciences Union. 


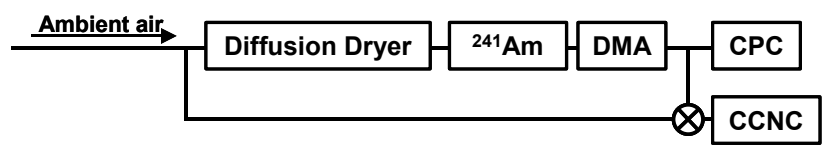

Fig. 1. CCN observation system used for this study. The three-way valve placed upstream of the CCN counter was used to select the sampling mode (see text for detailed explanation).

CCN concentrations are often influenced by anthropogenic particles (Twomey, 1974; Hudson and Yum, 2002). In recent years, anthropogenic emission of aerosol precursors (e.g. $\mathrm{SO}_{2}$ and $\mathrm{NO}_{\mathrm{x}}$ ) from Asia has increased significantly (Streets et al., 2000; Akimoto et al., 2003; Richter et al., 2005). Remote sensing studies have indicated that the aerosol particles derived from anthropogenic pollutants from Asia have changed cloud radiative properties such as optical depth in this region (Chameides et al., 2002; Kawamoto et al., 2006). Thus, it is important to study CCN activity in this region for a more accurate assessment of the impact of anthropogenic aerosol on climate. However, only a few $\mathrm{CCN}$ studies have been performed in this region (e.g. Matsumoto et al., 1997; Yum et al., 2005), and the size-resolved $\mathrm{CCN} / \mathrm{CN}$ ratios have not been measured so far.

In this study, we have measured size-resolved $\mathrm{CCN} / \mathrm{CN}$ ratios and $\mathrm{CCN}$ number concentrations at Gosan, Jeju Island, Korea, in March and April 2005 during the United Nations Environmental Programme (UNEP) Atmospheric Brown Cloud - East Asian Regional Experiment 2005 (ABC-EAREX2005) campaign. In addition to the CCN measurements, aerosol chemical composition was simultaneously observed. Observed threshold diameters for CCN activation are compared with the mass fractions of aerosol chemical compositions. Threshold diameters for activation $\left(D_{\text {crit }}\right)$ are calculated and compared with the observed threshold diameter to investigate the controlling factors of $D_{\text {crit }}$.

\section{Theory}

The equilibrium water vapor pressure $(S)$ of an aerosol particle can be calculated by Köhler theory. According to the theory, $S$ is described as follows (e.g. Roberts et al., 2002; Mochida et al., 2006):

$\ln S=\frac{A}{d_{\mathrm{wet}}}-\frac{B d_{\mathrm{dry}}^{3}}{\left(d_{\mathrm{wet}}^{3}-d_{\mathrm{dry}}^{3}\right)}\left(A=\frac{4 M_{w} \sigma}{R T \rho_{w}} \quad B=\frac{M_{w}}{\rho_{w}} \frac{\sum_{i} \frac{v_{i} \phi_{i} \varepsilon_{i} m_{i}}{M_{i}}}{\sum_{i} \frac{m_{i}}{\rho_{i}}}\right)$

where $d_{\text {dry }}$ is the dry diameter of a particle and $d_{\text {wet }}$ is the diameter of a droplet under equilibrium conditions. The suffix $i$ denotes the properties of the $i$-th solute compound. $M_{w}$ is the molecular weight of water; $M_{i}$ is the molecular weight of solute; $\rho_{w}$ is the density of water; $\rho_{i}$ is density of solute; $\sigma$ is the surface tension; $R$ is the gas constant; $T$ is the temperature; $v_{i}$ is the stoichiometric number of ions and molecule; $\phi_{i}$ is the osmotic coefficient; $\varepsilon_{i}$ is the degree of dissolution; and $m_{i}$ is the mass mixing ratio of the $i$-th solute. The first term on the right-hand side represents an increase in the equilibrium vapor pressure of water due to surface tension (the Kelvin effect). The second term on the right-hand side denotes the decrease in the equilibrium vapor pressure of water because of solute mixing (Raoult's effect). When we consider $S$ for an aerosol particle, it has a maximum value at a certain $d_{\text {wet }}$ (critical droplet diameter). The supersaturation ( $S S: S S=S-1$ ) that corresponds to this $S$ is called the critical supersaturation $\left(S S_{c}\right)$. Particles can be activated to cloud droplets if the $S S$ of the environment is higher than their $S S_{c}$.

If we assume that $A$ and $B$ are constants and $d_{\text {wet }}$ is much larger than $d_{\mathrm{dry}}, S S_{c}$ can be expressed as follows:

$$
\ln \left(1+S S_{c}\right)=\sqrt{\frac{4 A^{3}}{27 B d_{\mathrm{dry}}^{3}}} .
$$

This equation shows that $S S \mathrm{c}$ decreases with particle diameter. Thus, at a certain $S S$, there exists a threshold value of $d_{\text {dry }}$ above which all aerosol particles act as CCN. We denote this diameter as the critical dry diameter $\left(D_{\text {crit }}\right)$.

\section{Experiment}

\subsection{CCN measurement}

Figure 1 shows the CCN observation system used for this study. In this system, the relative humidity of the sample flow was reduced using two diffusion dryers in series (TSI Model 3062). Silica gel was replaced periodically (about 1 time in 10 days), and no systematic change in size-resolved $\mathrm{CCN}$ spectra was observed before or after the replacement. Then, particles were charged with a ${ }^{241}$ Am bipolar neutralizer and introduced to a differential mobility analyzer (DMA: TSI Model 3081). The DMA classified particles by their electrical mobility. The voltage applied to the DMA was scanned stepwise to change the diameter of the classified particle (Table 1). The sheath to-sample flow ratio of the DMA was set to 10:1. Classified particles were introduced to a condensation particle counter (CPC: TSI Model 3022) and a cloud condensation nuclei counter (CCNC: Droplet Measurement Technologies, Inc.) (Roberts and Nenes, 2005). The CPC monitored the number concentrations of condensation nuclei $(\mathrm{CN})$, and the $\mathrm{CCNC}$ measured number concentrations of CCN. The sample flow rate of the CCNC was set to $0.045 \mathrm{l} / \mathrm{min}$, and the sheath flow rate was set to $0.455 \mathrm{l} / \mathrm{min}$. The temperature gradient $(\Delta T)$ of the thermal gradient chamber in the CCNC was changed periodically to alter the $S S$ in the chamber. Four $\Delta T \mathrm{~s}(3.08,4.62,9.24$, and $15.4 \mathrm{~K}$ ) were used in this study. $S S$ s corresponding to these $\Delta$ Ts were calibrated with ammonium sulfate particles 
Table 1. Calibration results and operating conditions of the CCN measurement system shown in Fig. 1. SS was calculated at $300 \mathrm{~K}$ and $72 \mathrm{mN} / \mathrm{m}$ by the ideal solution approximation. The values in parentheses show $S S$ calculated using the osmotic coefficient of Clegg et al. (1996).

\begin{tabular}{llll}
\hline$\Delta T(\mathrm{~K})$ & Activation dry diameter of $\left(\mathrm{NH}_{4}\right)_{2} \mathrm{SO}_{4}(\mathrm{~nm})$ & $S S(\%)$ & Particle diameters classified by the DMA(nm) \\
\hline 3.08 & $125 \pm 3$ & $0.097(0.10)$ & $80,100,110,120,130,140,160,180,200,240,290$ \\
4.62 & $63 \pm 2$ & $0.27(0.30)$ & $60,65,70,75,80,85,90,100,130,160,200,240,290$ \\
9.24 & $38 \pm 1$ & $0.58(0.65)$ & $35,40,45,50,60,70,80,100,130,160,200,240,290$ \\
15.4 & $27 \pm 1$ & $0.97(1.1)$ & $25,30,35,40,50,60,80,100,130,160,200,240,290$ \\
\hline
\end{tabular}

as described by Kuwata et al. (2007). The calibration was performed at the observation site before and after the campaign. There are several different methods for the calculation of the water activity of ammonium sulfate particles (Kreidenweis et al., 2005, and references therein). We chose the ideal solution approximation $(\phi=1)$ in calculating the $D_{\text {crit }}$ of atmospheric particles (Sect. 5). Therefore we used this approximation for the interpretation of the calibration results to ensure consistency, although $S S$ s calculated using the osmotic coefficient of Clegg et al. (1996) are likely to be more plausible than the ideal solution approximation, as it is based on precise experimental data. We also show $S S$ s calculated using the osmotic coefficients by Clegg et al. (1996) for reference in parentheses in Table 1. The Debye - Hückel constant is needed to calculate the osmotic coefficient of Clegg et al. (1996) because it is based on the Pitzer model. The Debye - Hückel constant at $300 \mathrm{~K}$ was calculated by the equation given by Clegg et al. (1994).

Multiply charged particles were included in the classified particles, therefore an inverse analysis was performed for $\mathrm{CCN}$ and $\mathrm{CN}$ size distribution data for multiple-charge correction. The STWOM algorithm (Markowski, 1987) was used to obtain size distributions of $\mathrm{CN}$ and $\mathrm{CCN}$. In this calculation, the equilibrium charge distribution (Wiedensohler, 1988) and the DMA transfer function derived by Knutson and Whitby (1975) were included in the kernel function. The raw data for $\mathrm{CN}$ and $\mathrm{CCN}$ were linearly interpolated so that the interval of each bin was $\Delta \log d_{p}=0.015$. Size-resolved CCN/CN ratios were calculated using the data after the inverse analysis.

The three-way valve in Fig. 1 was switched once every $30 \mathrm{~min}$ for the direct measurement of the $\mathrm{CCN}$ number concentration in ambient air. It took $30 \mathrm{~min}$ for the measurement at each $S S$, and $2 \mathrm{~h}$ were required for the entire measurement cycle.

\subsection{Measurements of aerosol composition, size distribution}

Inorganic components $\left(\mathrm{NH}_{4}^{+}, \mathrm{Na}^{+}, \mathrm{K}^{+}, \mathrm{Ca}^{2+}, \mathrm{Mg}^{2+}, \mathrm{NO}_{3}^{-}\right.$, $\mathrm{SO}_{4}^{2-}, \mathrm{Cl}^{-}$) were measured by a particle-into-liquid sampler combined with ion chromatography (PILS-IC) (Orsini et al., 2003; Takegawa et al., 2005). The concentration of water- soluble organic carbon (WSOC) was measured by PILS combined with a total organic carbon analyzer (PILS-WSOC) (Sullivan et al., 2004; Miyazaki et al., 2006, 2007). Elemental carbon (EC) and organic carbon (OC) were measured by a semi-continuous thermal-optical carbon aerosol analyzer (Sunset Laboratory, Inc.) (Bae et al., 2004; Kondo et al., 2006; Miyazaki et al., 2006). $\mathrm{PM}_{2.5}$ cyclones were used for these instruments. The detection limits of the PILS-IC, PILS-WSOC, OC, and EC were estimated to be $0.01 \mu \mathrm{g} / \mathrm{m}^{3}, 0.1 \mu \mathrm{g} / \mathrm{m}^{3}, 1.0 \mu \mathrm{g} / \mathrm{m}^{3}$, and $0.2 \mu \mathrm{g} / \mathrm{m}^{3}$, respectively (Takegawa et al., 2005; Kondo et al., 2006; Miyazaki et al., 2006).

Aerosol number size distribution $(10-300 \mathrm{~nm})$ was measured with a scanning mobility particle sizer (SMPS 3936, TSI). The SMPS used in this study comprised a DMA (TSI Model 3081) and a CPC (TSI Model 3010). In addition, the number concentration of particles larger than $10 \mathrm{~nm}(\mathrm{CN})$ was measured by another CPC (TSI Model 3010) (Yum et al., 2007). The concentration of carbon monoxide (CO) was measured using a non-dispersive infrared analyzer (Horiba APMA-360 model) (Tanimoto et al., 2007).

\subsection{Measurement site}

The observations were performed between 18 March and 5 April 2005 at Gosan $\left(33.2^{\circ} \mathrm{N}, 126.1^{\circ} \mathrm{E}\right)$ on Jeju Island, Korea, as part of the Atmospheric Brown Cloud - East Asian Regional Experiment 2005 campaign. The location of Gosan is shown in Fig. 2. The instruments were placed in a container located about $10 \mathrm{~m}$ back from the edge of a cliff. The sampling inlets were made of stainless steel tubes with an inner diameter of $7 \mathrm{~mm}$. The top of the inlets was located about $4 \mathrm{~m}$ a.g.l.

The meteorological parameters at the Gosan site were observed by the Korean Meteorological Administration (KMA). During the observation period, the dominant winds were northerlies and north-northwesterlies (more than 50\% of the observation period) associated with the Siberian highpressure system. This led to the frequent transport of anthropogenic pollutants from the Korean Peninsula and China to Gosan. Sawa et al. (2007) attributed the high concentrations of $\mathrm{CO}$ at Gosan to the emissions from these regions based 


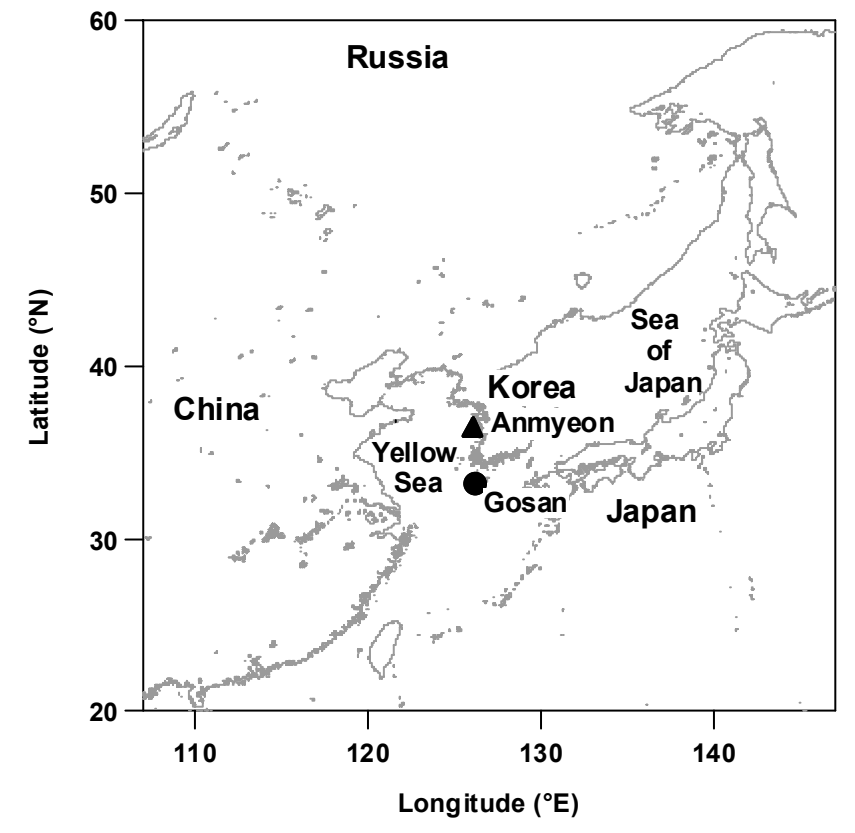

Fig. 2. Map of Gosan and surrounding region.

on tagged CO-tracer simulations. More detailed descriptions of the meteorological conditions and the transport of anthropogenic pollutants can be found elsewhere (Sawa et al., 2007; Miyazaki et al., 2007). Previous studies have also shown that air masses observed at Gosan are heavily influenced by anthropogenic emissions from East Asia (Carmichael et al., 1997; Lee et al., 2006).

\section{Results}

\subsection{CCN/CN size distributions}

Figure 3 shows the average size-resolved $\mathrm{CCN} / \mathrm{CN}$ ratio at $S S=0.097 \%$, together with the data on specific days. The $\mathrm{CCN} / \mathrm{CN}$ size distribution of ammonium sulfate obtained during calibration at the observation site (closed circles) is also shown in this figure for comparison. In general, $\mathrm{CCN} / \mathrm{CN}$ increases with increasing diameter. At 02:0002:30 on $26 \mathrm{March}$, the CCN/CN size distribution of ambient particles was very similar to that of ammonium sulfate. On the other hand, on 28 March, the CCN/CN size distribution shifted to a larger diameter, and the rate of increase was lower than ammonium sulfate. In addition, the spectrum is significantly different from a sigmoid function. This shift indicates that the bulk aerosol chemical composition on 28 March was significantly different from ammonium sulfate. The slower rate of increase indicates the co-existence of different types of aerosol particles with different activation curves. A convolution of sigmoid functions is not necessarily a sigmoid function. Thus, the non-sigmoid shape of the spectrum can be interpreted as a result of the co-existence of different types

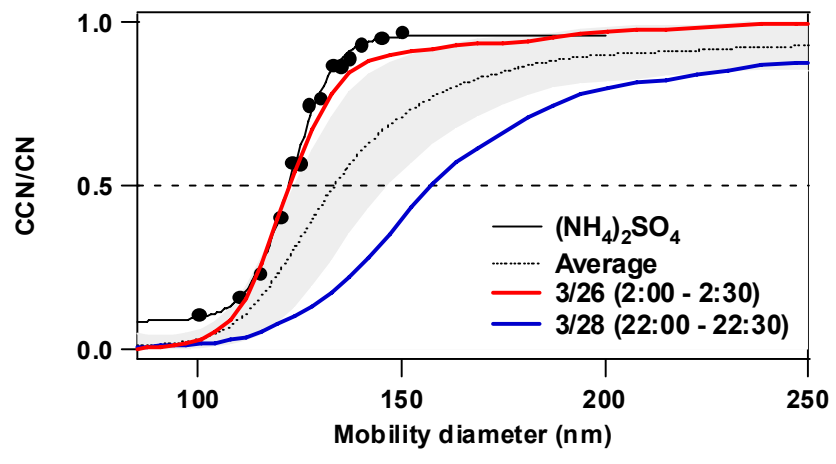

Fig. 3. Size distributions of $\mathrm{CCN} / \mathrm{CN}$ ratios of ammonium sulfate and atmospheric particles at $S S=0.097 \%$. The average, standard deviation (gray area), and two examples of $\mathrm{CCN} / \mathrm{CN}$ during the observation period are shown. The solid circles denote the experimental data for ammonium sulfate under the observation conditions and the solid line shows the fitting results of the experimental data.

of aerosol particles. The different width of the DMA transfer function at $D_{50}$ in diameter space ( $\sim 25 \%$ : estimated by a Knutson-type DMA transfer function) is not large enough to explain the lower increase rate, as the widths of the activation curves are different by about a factor of 2 .

We defined the threshold diameter for $\mathrm{CCN}$ activation to compare it with the mass fraction of chemical compounds and theoretically calculated $D_{\text {crit }}$. In this study, the threshold diameter was defined as the diameter corresponding to $\mathrm{CCN} / \mathrm{CN}=0.5\left(D_{50}\right)$ because it represents the bulk chemical composition. If aerosol particles were not fully activated, $D_{50}$ would not necessarily correspond to the threshold diameter. In all cases shown in Fig. 3, the $\mathrm{CCN} / \mathrm{CN}$ ratios exceeded 0.85 at $250 \mathrm{~nm}$. In addition, no multi-step activation was observed. These results suggest the appropriateness of the definition of the unique activation diameter $\left(D_{50}\right)$. Previous studies on CCN activity of laboratory-generated particles have shown that $D_{50}$ can be quantitatively compared with the theoretically calculated activation diameters (e.g. Corrigan and Novakov, 1999; Raymond and Pandis, 2002).

\subsection{Temporal variation of $\mathrm{CCN}$ and particle number size distribution}

\subsubsection{CCN number concentration}

Figure 4a shows the time series of the $\mathrm{CCN}$ number concentration. In general, the variation in the $\mathrm{CCN}$ number concentration was correlated with that of $\mathrm{CO}$ concentration (Fig. 4d). In particular, this correlation is clearly observed at $S S=0.097 \%\left(r^{2}=0.74\right)$. Sawa et al. (2007) have reported high CO concentration between 22-24 March and 30 March2 April due to transport of $\mathrm{CO}$ from the Korean Peninsula and China. During these periods, CCN concentration also increased (Fig. 4a and d). CO is emitted mainly by the incomplete combustion of fossil fuels and biomass, and it is a 
a)

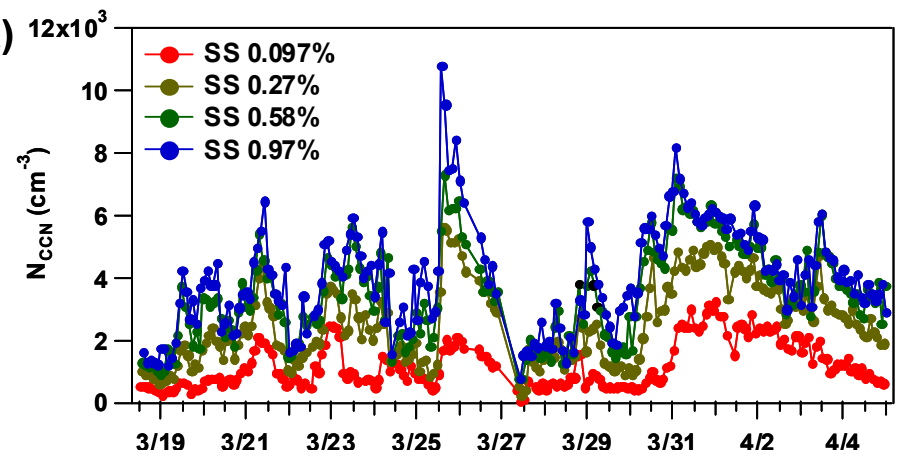

b)

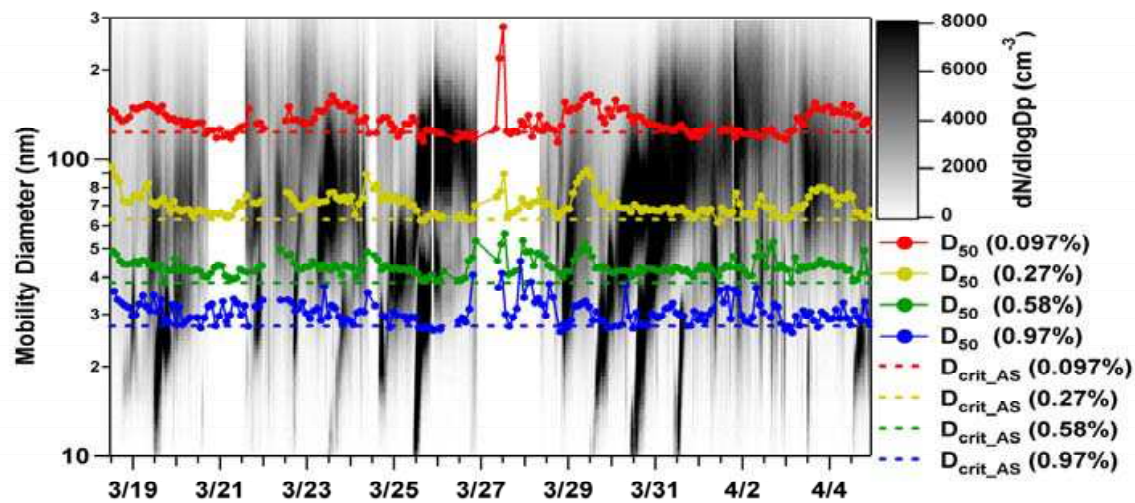

c)

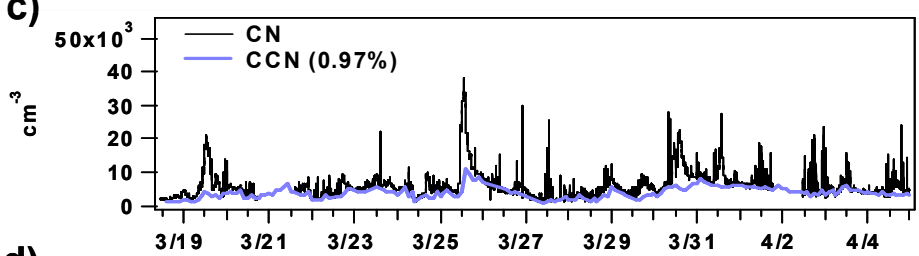

d)

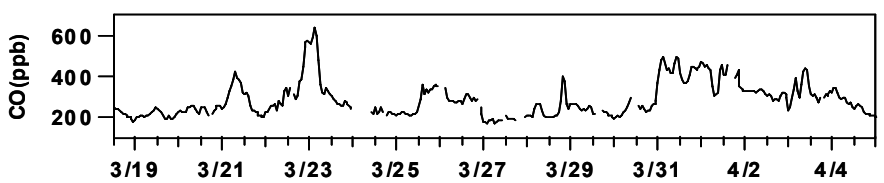

Fig. 4. Time series of (a) CCN number concentration, (b) aerosol size distribution, $D_{50}$, (c) $\mathrm{CN}$ concentration, $\mathrm{CCN}(S S=0.97 \%)$ concentration, and (d) CO concentration. The dashed lines in (b) shows the $D_{\text {crit }}$ of ammonium sulfate at each $S S$.

good indicator of emissions from combustion sources. Primary aerosols and aerosol precursors such as $\mathrm{SO}_{2}$ and $\mathrm{NO}_{\mathrm{x}}$ are co-emitted with $\mathrm{CO}$. Thus, these high $\mathrm{CCN}$ concentrations were likely caused by the enhanced concentrations of anthropogenic aerosols transported from these regions. The average values and standard deviations of $\mathrm{CCN}$ number concentration are shown in Table 2. The average CCN number concentration at $S S=0.097 \%$ and $0.97 \%$ was $1200 \mathrm{~cm}^{-3}$ and $4000 \mathrm{~cm}^{-3}$, respectively. These concentrations are higher than those of other remote areas of the world such as the Island of Tasmania in Australia and Mace Head in Ireland by about an order of magnitude (Covert et al., 1998; Reade et al., 2006). CCN concentrations measured at Gosan during this observation period were extensively compared with those obtained in other regions by Yum et al. (2007). The CCN con- centrations observed in this study are close to those of Anmyeon (Korea: see Fig. 2) in springtime of 2004 ( $S S=1 \%$ ) (Yum et al., 2005).

\subsection{2 $\quad D_{50}$}

Figure $4 \mathrm{~b}$ shows the time series of the number size distribution of aerosol particles and $D_{50}$. The $D_{\text {crit }}$ of ammonium sulfate at each $S S$ is also shown as dashed lines in this figure. The average values of $D_{50}$ at $S S=0.097 \%$ and $0.97 \%$ were $136 \mathrm{~nm}$ and $31 \mathrm{~nm}$, respectively (Table 2). In general, the $D_{50}$ is almost equal to or slightly larger (by $\sim 25 \%$ ) than the $D_{\text {crit }}$ of ammonium sulfate $(125 \mathrm{~nm}$ and $27 \mathrm{~nm}$, respectively). This means that the $D_{\text {crit }}$ of ammonium sulfate is the smallest $D_{\text {crit }}$ of the atmospheric particles during the observation period. 
Table 2. Average values and standard deviations of the CCN number concentration, $D_{50}$, and $B$. The surface tension of water was assumed for the calculation of $B$.

\begin{tabular}{llll}
\hline$S S(\%)$ & CCN number concentration $\left(\mathrm{cm}^{-3}\right)$ & $D_{50}(\mathrm{~nm})$ & $B$ \\
\hline 0.097 & $1194 \pm 746$ & $136 \pm 17$ & $0.61 \pm 0.17$ \\
0.27 & $2543 \pm 1277$ & $71 \pm 6$ & $0.55 \pm 0.12$ \\
0.58 & $3496 \pm 1510$ & $44 \pm 3$ & $0.50 \pm 0.09$ \\
0.97 & $3996 \pm 1686$ & $31 \pm 3$ & $0.55 \pm 0.13$ \\
\hline
\end{tabular}

The temporal variation of $D_{50}$ at different $S S$ s did not always correlate. As shown in Eq. (2), the threshold diameter for $\mathrm{CCN}$ activation depends on $A$ and $B$, which are determined by the aerosol chemical composition. Thus, this difference in the temporal variations of $D_{50}$ at each $S S$ indicates the difference in temporal variation of chemical composition in different size ranges.

Using Eq. (2), we calculated $B$ assuming the surface tension of water. This parameter gives information on the chemical composition (approximate number of solute ions and molecules included in a unit volume) at $D_{50}$ for each $S S$. The results are summarized in Table 2. The average values of $B$ did not depend on $S S$ significantly, indicating that the chemical composition averaged over the observation period was rather uniform in the diameter range considered (30 to $160 \mathrm{~nm})$.

\subsubsection{Number size distribution}

New particle formation events can have a significant impact on CCN number concentration (e.g. O'Dowd et al., 2002; Laaksonen et al., 2005). In Fig. 4b, new particle formation is clearly identified on 19, 25, 29, 30 and 31 March. It can be seen more clearly in Fig .4c, which shows the particle number concentration measured by $\mathrm{CPC}$ and $\mathrm{CCN}$ number concentration $(S S=0.97 \%)$. The concentration of $\mathrm{CCN}$ ( $S S=0.97 \%$ ) is a good indicator of particle number concentrations larger than $30 \mathrm{~nm}$, as the average value of $D_{50}$ at $S S=0.97 \%$ is $31 \pm 3 \mathrm{~nm}$ (Table 2). Thus, the difference of the number concentrations (CN-CCN $(S S=0.97 \%)$ ) represents the number concentration of particles between 10 and $30 \mathrm{~nm}$. During the periods of new particle formation events described above, an enhancement of the number concentration of small (10-30 nm) particles was observed, as indicated by the large gap between $\mathrm{CN}$ and $\mathrm{CCN}$ concentrations. In particular, the events occurring on 29 and 30 March were important in that newly formed particles influenced the $\mathrm{CCN}$ number concentration as a consequence of particle growth beyond $D_{50}$. Figure $5 \mathrm{a}$ and $\mathrm{b}$ shows the CCN number concentrations, particle size distributions, and $D_{50}$ during this event. The peak diameter of the size distribution obtained by bimodal lognormal fitting is shown as red lines in Fig. 5 b.
At 14:00 local time (LT) on 29 March, small $(<20-n m)$ particles appeared and began to grow. The peak diameter grew to $25 \mathrm{~nm}$ by 18:00 LT, and some particles grew larger than the $D_{50}$ at $S S=0.97 \%(28 \mathrm{~nm})$. At this time, the CCN number concentration $(S S=0.97 \%)$ began to increase. The peak diameter and $D_{50}(S S=0.97 \%)$ were equal at 21:00 LT (blue dashed vertical line in Fig. 5b). At this time, the majority of newly formed particles began to act as CCN at $S S=0.97 \%$. In the case of $S S=0.58 \%$, the peak diameter equaled $D_{50}$ at 2:00 LT on 30 March , and the CCN number concentration increased from $1700 \mathrm{~cm}^{-3}$ (01:30 LT) to $5800 \mathrm{~cm}^{-3}(11: 30 \mathrm{~L} T)$. At 03:00 LT, some portion of the particles grew large enough to act as $\mathrm{CCN}$ at $S S=0.27 \%$. Then, $\mathrm{CCN}$ number concentration at $S S=0.27 \%$ increased from 1000 to $4700 \mathrm{~cm}^{-3}$ with the increase in the peak diameter. For this $S S$, the peak diameter reached $D_{50}$ at 10:00 LT. At the same time, another new particle formation event occurred, and this event also clearly affected the CCN number concentration at $S S=0.97 \%$ and $0.58 \%$. At $12: 00 \mathrm{LT}$, some fraction of the particles grew larger than the $D_{50}$ at $S S=0.097 \%$, and they affected the CCN number concentration at this $S S$. A similar phenomenon was also observed on 25 March (Fig. 4a and b). These results clearly show that the newly formed particles significantly increased the CCN number concentration.

Buzorius et al. (2004) have shown that the deliquescence relative humidity and the hygroscopic growth of newly formed particles at Gosan during the ACE-Asia campaign were similar to those of ammonium sulfate. This suggests that newly formed particles were mainly composed of inorganic compounds because no organic compounds in the atmosphere are known to be as hygroscopic as ammonium sulfate. In addition, according to Buzorius et al. (2004), glutaric acid is the only organic compound that is known to have a deliquescence relative humidity similar to ammonium sulfate. However, the hygroscopic growth of glutaric acid is less than ammonium sulfate. For instance, Cruz and Pandis (2000) measured the hygroscopic growth factors of glutaric acid and ammonium sulfate particles to be 1.1 and 1.5 at a relative humidity of $85 \%$, respectively. This also supports the conclusion of their study that newly formed particles were mainly composed of ammonium sulfate at Gosan. In the present study, the observed $D_{50}$ of newly formed particles 
(a)

(b)

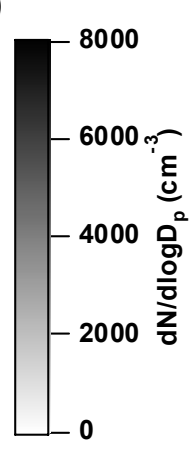

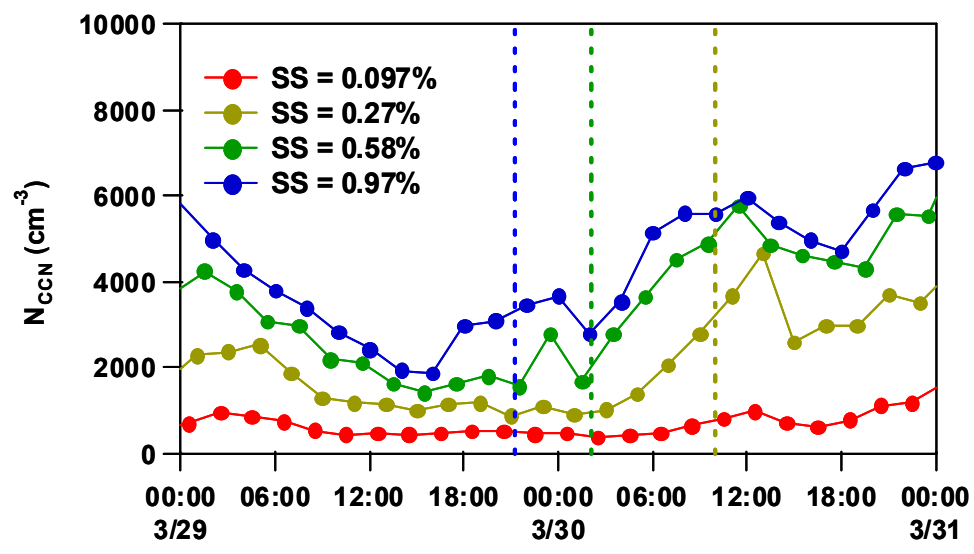

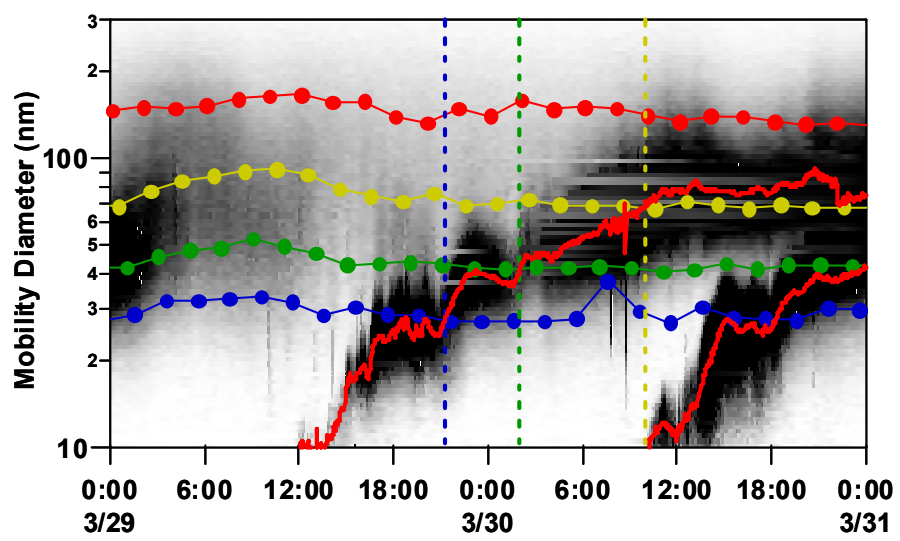

Fig. 5. Close-up of Fig. 4 during the new particle formation events from 29-31 March. The (a) time series of CCN number concentration and (b) the number size distribution and $D_{50}$ (line with filled circles) are shown. The red solid lines in (b) denote the peak diameters obtained by bimodal lognormal fitting. The vertical dashed lines show the time at which the peak diameter and $D_{50}$ were equal.

was also similar to ammonium sulfate. For instance, the $D_{50}$ for $S S=0.97 \%$ was $27 \mathrm{~nm}$ at 21:00 LT, 29 March, and for $S S=0.27 \%$ it was $66 \mathrm{~nm}$ at 10:00 LT, 30 March. The $D_{\text {crit }}$ of ammonium sulfate was $27 \mathrm{~nm}$ and $63 \mathrm{~nm}$, respectively (Table 1).

Previous studies have suggested that new particle formation has an impact on the CCN number concentration from the measurements of number size distributions (e.g. O'Dowd et al., 2002; Laaksonen et al., 2005) and modeling (e.g. Arnold, 2006; Sotiropoulou et al., 2006). The present observations clearly demonstrate that new particle formation is one of the important processes of CCN formation at Gosan.

Figure 6 shows the number size distribution of all particles and CCN averaged over the whole observation period. Average $\mathrm{CCN} / \mathrm{CN}$ ratios were multiplied by the number size distribution measured by the SMPS averaged over the observation period to obtain a rough estimate of the $\mathrm{CCN}$ size distribution. The peak diameter of the average $\mathrm{CCN}$ size distribution was about $150 \mathrm{~nm}$ at $S S=0.097 \%$ and shifted to about $80 \mathrm{~nm}$ at $S S=0.97 \%$. Detailed discussion of the number size distribution of particles during the observation period has been given by Yum et al. (2007).

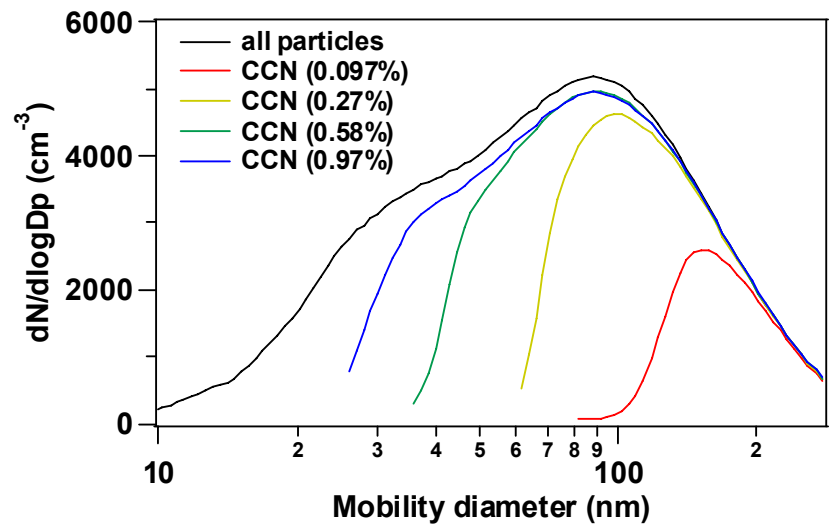

Fig. 6. Number size distribution of particles and $\mathrm{CCN}$. CCN size distributions were estimated by multiplying $\mathrm{CCN} / \mathrm{CN}$ ratios by the number size distribution. The data were averaged over the whole observation period. The data range of CCN size distributions was limited by the scanning range of the DMA. 


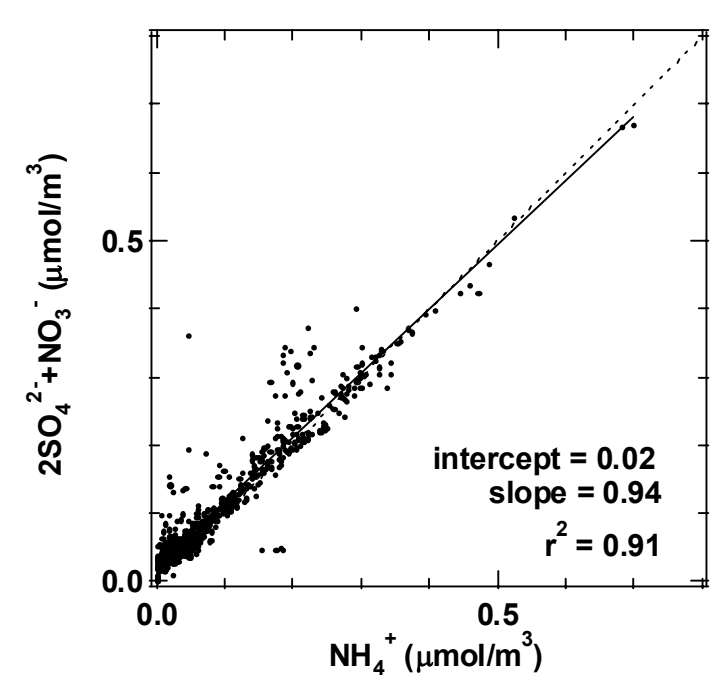

Fig. 7. Ion balance between ammonium, sulfate, and nitrate ions.

\subsection{Ion balance of inorganic components}

The average concentrations of the inorganic components measured by PILS-IC are summarized in Table $3 . \mathrm{NH}_{4}^{+}$was the most abundant cation (56\%), and $\mathrm{Ca}^{2+}$ was the second (15\%). $\mathrm{SO}_{4}^{2-}$ was the most abundant anion (67\%). Topping et al. (2004) measured inorganic components using a Berner impactor at Gosan during the ACE-Asia campaign. They showed that the concentration of $\mathrm{NH}_{4}^{+}$was the highest at the $0.2-0.5 \mu \mathrm{m}$ stage, and $\mathrm{Ca}^{2+}$ was the highest at the $1.5-5.5 \mu \mathrm{m}$ stage. In this study, the $D_{50}$ values were in the sub-micrometer range (Fig. 4). Thus, $\mathrm{Ca}^{2+}$ was ignored in the following discussion of $\mathrm{CCN}$ activity. $\mathrm{Na}^{+}, \mathrm{Mg}^{2+}$, and $\mathrm{Cl}^{-}$were also ignored for the same reason.

Figure 7 shows the ion balance of $\mathrm{NH}_{4}^{+}, \mathrm{NO}_{3}^{-}$, and $\mathrm{SO}_{4}^{2-}$. The cation and anions balance very well (slope $=0.94$ ). This result shows that sulfate and nitrate in $\mathrm{PM}_{2.5}$ were neutralized by ammonium at Gosan. The addition of $\mathrm{K}^{+}$to the ion balance causes the balance to deviate from the 1:1 line. This suggests that neither $\mathrm{NO}_{3}^{-}$nor $\mathrm{SO}_{4}^{2-}$ were the counter ions of $\mathrm{K}^{+}$. In addition, because the molar concentration of $\mathrm{K}^{+}$was only $8 \%$ of $\mathrm{NH}_{4}^{+}$, we ignored $\mathrm{K}^{+}$. In the following discussion, we assume that the inorganic component of sub-micron particles was composed only of ammonium sulfate and ammonium nitrate.

\section{Discussion}

\subsection{Temporal variation of $\mathrm{D}_{50}$ and aerosol composition}

Figure 8 shows the temporal variation of $D_{50}(S S=0.097 \%)$ and the mass fraction of the aerosol components. In this figure, the aerosol components were divided into four groups: inorganic $\left(\mathrm{NH}_{4}^{+}+\mathrm{SO}_{4}^{2-}+\mathrm{NO}_{3}^{-}\right)$, WSOC, water-insoluble

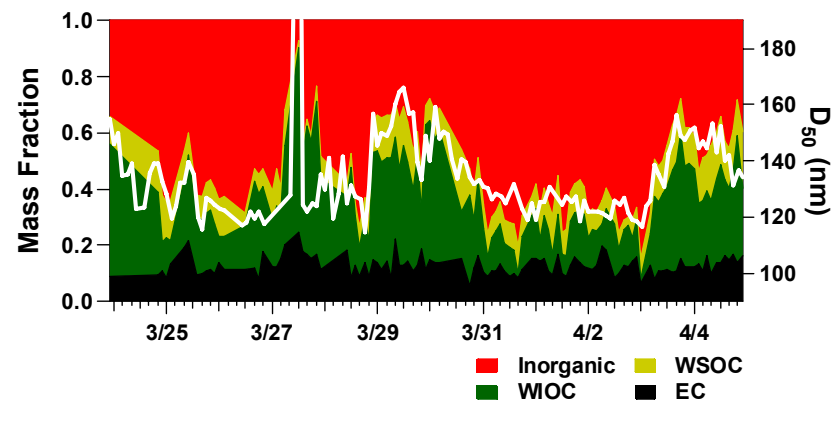

Fig. 8. Temporal variation of the mass fraction of aerosol components and $D_{50}$ at $S S=0.097 \%$. Here, "inorganic" denotes the sum of ammonium sulfate and ammonium nitrate.

organic carbon (WIOC $=$ OC - WSOC), and EC. Inorganic components and WSOC are soluble in water, while WIOC and EC are insoluble in water. Note that the masses of WSOC and WIOC are the masses of carbon in organic compounds and do not include the masses of other elements (e.g. oxygen and hydrogen) (Kondo et al., 2007). The temporal variation of $D_{50}$ and the water-soluble fraction (inorganic + WSOC) are correlated. With an increase in the water-soluble fraction, $D_{50}$ decreases. This is consistent with Köhler theory because the value of $B$ in Eq. (2) increases with an increase in the water-soluble fraction. In this case, the variation in $D_{50}$ was as small as about $40 \mathrm{~nm}$. Thus, $D_{50}$ is correlated with the water-soluble fraction almost linearly, although the relationship is not always linear, as anticipated from Eqs. (1) and (2). This good correlation indicates that the variation of $D_{50}$ was not significantly influenced by the variation in the chemical composition of the water-soluble component (e.g change of inorganic/WSOC ratio). Kim et al. (2006) have shown that the hygroscopicity of aerosol particles at Gosan was correlated with the mass fraction of sulfate. This indicates that $B$ is mainly determined by inorganic components because hygroscopicity is mainly determined by $B$ (e.g. Kreidenweis et al., 2005; Mochida et al., 2006). This is consistent with the present observations because the mass fraction of inorganic compounds was significantly larger than that of WSOC during this period (Fig. 8).

The $D_{50}$ at $S S=0.097 \%$ did not necessarily correlate with those of higher $S S$ s (Fig. 4b), as discussed in Sect. 4.2.2. Correlation of $D_{50}$ at $S S=0.097 \%$ with those at higher $S S$ s decreased with the increase in $S S\left(r^{2}=0.25\right.$ and 0.00 for $S S=0.27 \%$ and $0.97 \%$, respectively). This indicates that the temporal variation of the mass fraction of $\mathrm{PM}_{2.5}$ was reflected in that of $D_{50}$ at $S S=0.097 \%(100-200 \mathrm{~nm})$ but was not reflected in $D_{50}$ at higher $S S \mathrm{~s}(<100 \mathrm{~nm})$. This is because the contribution to the $\mathrm{PM}_{2.5}$ mass concentration of particles with diameters smaller than $100 \mathrm{~nm}$ was much smaller than that of $100-200 \mathrm{~nm}$. 
Table 3. Average concentration of inorganic components during the observation period.

\begin{tabular}{llllllll}
\hline $\mathrm{NH}_{4}^{+}$ & $\mathrm{Na}^{+}$ & $\mathrm{K}^{+}$ & $\mathrm{Ca}^{2+}$ & $\mathrm{Mg}^{2+}$ & $\mathrm{NO}_{3}^{-}$ & $\mathrm{SO}_{4}^{2-}$ & $\mathrm{Cl}^{-}$ \\
\hline $1.57\left(\mu \mathrm{g} / \mathrm{m}^{3}\right)$ & 0.38 & 0.26 & 0.43 & 0.18 & 1.44 & 3.96 & 0.49 \\
\hline
\end{tabular}

\subsection{Comparison of $D_{50}$ and calculated $D_{\text {crit }}$}

In this section, we compare the observed $D_{50}$ and the $D_{\text {crit }}$ calculated from the simultaneously measured chemical composition. We first discuss the assumptions used to calculate $A$ and $B$ in Köhler theory (Sect. 2). The surface tension of water $(72 \mathrm{mN} / \mathrm{m})$ was assumed for the calculation of $A$. The calculation was performed at $T=300 \mathrm{~K}$. For the calculation of $B$, the ideal solution approximation $(\phi=1)$ was used. We used the simultaneously measured aerosol chemical composition $\left(\mathrm{PM}_{2.5}\right)$ assuming that chemical composition was not size-dependent. Assumptions regarding the chemical composition and chemical properties of organic compounds (e.g. molecular weight (MW), elemental ratio, density) are also required for the calculation of $B$. Kawamura et al. (2003) and Mochida et al. (2003) measured dicarboxylic acids and other water-soluble organic compounds over the Sea of Japan and Yellow Sea during the ACE-Asia campaign. The concentration of oxalic acid was higher than that of other compounds by an order of magnitude. Simoneit et al. (2004) also measured dicarboxylic acids at Gosan during the ACE-Asia campaign. Adipic acid was the largest-MW linear molecule among the dicarboxylic acids they measured. Oxalic acid has one of the smallest molecular weights among atmospheric aerosol organic compounds. Therefore, if we assume that all carbon atoms in WSOC originated from oxalic acid, we will estimate a maximum Raoult's effect. In this study, this assumption is called as "oxalic acid assumption". As an extreme case, we calculated $D_{\text {crit }}$ using this assumption. The average molecular weight of WSOC should be higher than that of oxalic acid because dicarboxylic acids and saccharides with larger molecular weights were also observed at Gosan (Simoneit et al., 2004). In fact, Miyazaki et al. (2007) indicated that a significant portion of WSOC measured during the ABC-EAREX2005 campaign could be attributed to organic compounds having a MW larger than oxalic acid. To test the sensitivity of $D_{\text {crit }}$ to the assumed WSOC composition, we also calculated $D_{\text {crit }}$ assuming that the average properties (MW, elemental composition, and density) of water-soluble organic compounds are equal to those of adipic acid. In this study, this assumption is called the "adipic acid assumption", although this does not mean that all WSOC originated from adipic acid. In addition, recent studies have shown that significant fractions (20-60\%) of WSOC are high-molecular weight compounds such as humic-like substances (HULIS) (Graber and Rudich, 2006, and references therein). Calculating $D_{\text {crit }}$ under the assumption that

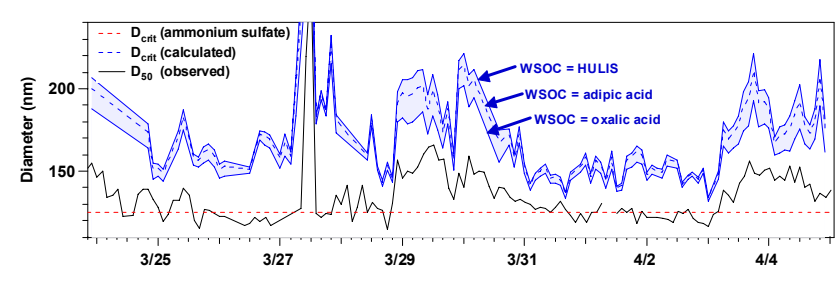

Fig. 9. Comparison of observed $D_{50}$ and calculated $D_{\text {crit }}$ at $S S=0.097 \%$. The upper and lower blue lines were calculated using the "HULIS assumption" and "oxalic acid assumption", respectively. See text for details of the calculations.

all WSOC originated from HULIS (HULIS assumption) corresponds to the lowest estimate of Raoult's effect. As in other cases, we need the chemical properties of HULIS for the calculation, although chemical properties of HULIS vary depending on the samples used (Graber and Rudich, 2006). For this calculation, we assumed an elemental composition of HULIS of C: $\mathrm{H}: \mathrm{O}=1$ : 1.16: 0.63 (Dinar et al., 2006a), a density of $1.5 \mathrm{~g} / \mathrm{cm}^{3}$ (Dinar et al., 2006b; Hoffer et al., 2006), and an average molecular weight of $700 \mathrm{Da}$ (Dinar et al., 2006a). In these calculations, water-soluble organic compounds were assumed to be completely dissolved in water $(\varepsilon=1)$.

The chemical properties of WIOC are also required for the calculation of $B$. Simoneit et al. (2004) have measured alkanes, fatty acids, and polycyclic aromatic hydrocarbons (PAHs) at Gosan. Among these compounds, the mass fractions of PAHs were very limited. Most of the carbon atoms of alkanes and fatty acids are in methylene groups $\left(-\mathrm{CH}_{2}-\right)$. Therefore, we assumed that all carbon atoms in WIOC originated from methylene groups. The density of WIOC was assumed to be $0.8 \mathrm{~g} / \mathrm{cm}^{3}$ because the densities of hydrocarbons and fatty acids are typically $0.7-0.9 \mathrm{~g} / \mathrm{cm}^{3}$ (Pang et al., 2006). The properties of EC were assumed to be equal to those of graphite. The values used for the calculation are summarized in Table 4.

The observed $D_{50}$ and calculated $D_{\text {crit }}$ at $S S=0.097 \%$ are compared in Fig. 9. This figure shows three calculated results based on the oxalic acid, adipic acid, and HULIS assumptions. In all cases, the temporal variations of the calculated $D_{\text {crit }}$ correlate with the observed $D_{50}$. However, the calculated $D_{\text {crit }}$ values are systematically larger than the observations by $20-29 \%$.

The correlations of $D_{50}$ and the calculated $D_{\text {crit }}$ (adipic acid assumption) are shown in Fig. 10. At all SSs, the 
Table 4. Values used for the calculation of $D_{\text {crit }} v$ for WIOC and EC are not shown here because they are insoluble in water.

\begin{tabular}{lllll}
\hline & Assumed composition & Molecular weight(MW) & $v$ & $\rho\left(\mathrm{g} / \mathrm{cm}^{3}\right)$ \\
\hline Ammonium sulfate & $\left(\mathrm{NH}_{4}\right)_{2} \mathrm{SO}_{4}$ & 132.14 & 3 & 1.77 \\
Ammonium nitrate & $\mathrm{NH}_{4} \mathrm{NO}_{3}$ & 80.04 & 2 & 1.72 \\
WSOC (oxalic acid) & $(\mathrm{COOH})_{2}$ & 90.04 & 1 & 1.9 \\
WSOC (adipic acid) & $\mathrm{HOOC}\left(\mathrm{CH}_{2}\right)_{4} \mathrm{COOH}$ & 146.14 & 1 & 1.36 \\
WSOC (HULIS) & $\mathrm{CH}_{1.16} \mathrm{O}_{0.63}$ & 700 & 1 & 1.5 \\
WIOC & $\left(-\mathrm{CH}_{2}-\right)$ & $14 /$ carbon atom & N/A & 0.8 \\
EC & $\mathrm{C}$ (graphite) & $12 /$ carbon atom & N/A & 2.0 \\
\hline
\end{tabular}

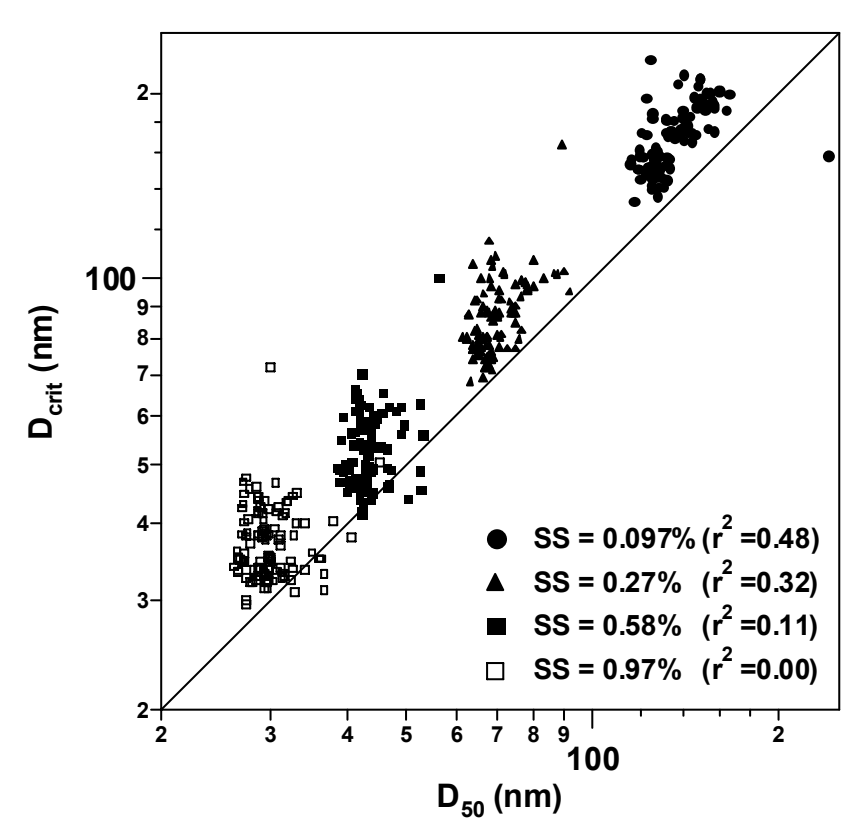

Fig. 10. Scatter plot of $D_{50}$ (observed) and calculated $D_{\text {crit }}$ (calculated). The adipic acid assumption was used for the calculation shown in this figure.

calculated diameters are larger than the observations. The differences between the calculated $D_{\text {crit }}$ and the observed $D_{50}$ (calc-obs) are summarized in Table 5 . In all cases, $D_{\text {crit }}$ was overestimated by 16-29\%.

The $r^{2}$ values decrease with increasing $S S$ (diminishing $\left.D_{50}\right)$. This is likely due to the size dependence of the temporal variation of the aerosol chemical composition, as discussed in Sect. 4.2.2.

\subsection{Possible causes of the discrepancy}

In this section, we discuss the possible causes of the difference between $D_{50}$ and $D_{\text {crit }}$ and identify critical assumptions for the calculation of $D_{\text {crit }}$.

In calculating $B$, we assumed the composition and chemical properties of each component. The average chemi- cal properties of water-soluble organic compounds were assumed to be identical to those of oxalic acid, adipic acid, or HULIS. Nevertheless, the $D_{\text {crit }}$ values were larger than $D_{50}$ even in the case of the oxalic acid assumption (the maximum estimation of $B$ ). Therefore, the assumption of the chemical composition of WSOC is not the main cause of this discrepancy.

We assumed a density of $0.8 \mathrm{~g} / \mathrm{cm}^{3}$ for water-insoluble organic compounds. If the actual density were larger than this value, this would lead to the overestimation of $D_{\text {crit }}$ because of the underestimation of $B$ (Eq. 1). However, a sensitivity study of the density of WIOC (up to $1.2 \mathrm{~g} / \mathrm{cm}^{3}$ ) under the oxalic acid assumption showed that calculated $D_{\text {crit }}$ still overestimated the observations $\left(D_{\text {crit }}-D_{50}=20 \pm 12 \mathrm{~nm}\right.$ at $S S=0.097 \%$ ).

The assumption of complete dissolution corresponds to the upper limit in estimated $B$, and therefore the lower limit of $D_{\text {crit }}$. For instance, Huff Hartz et al. (2006) showed that the $D_{\text {crit }}$ of slightly soluble organic compounds calculated using the complete dissolution assumption is smaller than $D_{\text {crit }}$ calculated assuming limited solubility. We used the ideal solution approximation in the calculation. If the discrepancy is due to this effect, the osmotic coefficient at the critical droplet diameters needs to be increased by a factor of about 2, considering the magnitude of the discrepancy (Table 5) and Eq. (2). Nevertheless, such a large change in the osmotic coefficient is unlikely, as the solution was very dilute at the critical droplet diameters.

In this study, the aerosol chemical composition was measured at $\mathrm{PM}_{2.5}$. If the chemical compositions of $\mathrm{PM}_{2.5}$ do not represent those at $D_{50}(<200 \mathrm{~nm})$, it causes an error in the calculation of $D_{\text {crit }}$. We discuss this point in detail in Sect. 5.3.1.

The surface tension of water was assumed for the calculation of $A$ in Eq. (2). If the decrease in surface tension due to WSOC was significant, it may affect the $D_{\text {crit }}$ (Facchini et al., 1999). This point is discussed in Sect. 5.3.2. 
Table 5. Differences between $D_{50}$ (observed) and calculated $D_{\text {crit }}\left(D_{\text {crit }}-D_{50}\right)$. The values in parentheses show the magnitude of the difference in \%. "Oxalic acid", "adipic acid", and "HULIS" show the oxalic acid, adipic acid, and HULIS assumptions, respectively.

\begin{tabular}{lllll}
\hline & $S S=0.097 \%$ & $0.27 \%$ & $0.58 \%$ & $0.97 \%$ \\
\hline Oxalic acid & $27 \pm 18(\mathrm{~nm})$ & $13 \pm 10$ & $7 \pm 7$ & $6 \pm 6$ \\
& $(20 \pm 12 \%)$ & $(18 \pm 13 \%)$ & $(16 \pm 15 \%)$ & $(21 \pm 19 \%)$ \\
Adipic acid & $34 \pm 19$ & $17 \pm 11$ & $9 \pm 8$ & $8 \pm 6$ \\
& $(26 \pm 13 \%)$ & $(24 \pm 15 \%)$ & $(22 \pm 17 \%)$ & $(27 \pm 22 \%)$ \\
HULIS & $39 \pm 20$ & $17 \pm 12$ & $10 \pm 8$ & $8 \pm 7$ \\
& $(29 \pm 14 \%)$ & $(25 \pm 16 \%)$ & $(23 \pm 18 \%)$ & $(26 \pm 23 \%)$ \\
\hline
\end{tabular}

\subsubsection{Size dependence of chemical composition}

Some studies have used size-resolved aerosol chemical composition for CCN closure studies (e.g. Cantrell et al., 2001; Roberts et al., 2002). These studies have shown the sizedependence of aerosol chemical composition. In addition, Medina et al. (2007) have shown that the use of size-resolved chemical composition can decrease the error in the closure of the CCN number concentration. Topping et al. (2004) measured size-resolved chemical composition at Gosan during the ACE-Asia campaign using a Berner impactor. They reported the size distribution of mass fractions of inorganic compounds and WSOC, and the results clearly showed the size-dependence. However, it is difficult to use their results to estimate the effect of size dependent chemical composition because they did not measure water-insoluble components of the impactor samples. Mochida et al. (2007) measured aerosol chemical compounds sampled with a MicroOrifice Uniform Deposit Impactor (MOUDI) over the East China Sea and the Sea of Japan during the ACE-Asia campaign. They found that the submicron mode was enriched by non-sea salt (nss)-SO ${ }_{4}^{2-}\left([\mathrm{OC}] /\left[\mathrm{nss}-\mathrm{SO}_{4}^{2-}\right] \approx 0.2\right.$ at $0.18-$ $0.56 \mu \mathrm{m}$ ), whereas the supermicron mode was enriched by organic compounds $\left([\mathrm{OC}] /\left[\mathrm{nss}-\mathrm{SO}_{4}^{2-}\right] \approx 1\right.$ at $\left.1.8-5.6 \mu \mathrm{m}\right)$. The median value of $[\mathrm{OC}] /\left[\mathrm{SO}_{4}^{2-}\right]$ in the present study is 1.0 , suggesting that $\mathrm{PM}_{2.5}$ chemical composition was affected by super-micron particles by comparison with the ratio of Mochida et al. (2007).

The $D_{\text {crit }}$ for each $S S$ was calculated using the chemical composition of the sub-micron mode particle given in Table 2 in Mochida et al. (2007) assuming that OC was entirely composed of WIOC, because the fraction of WSOC was much smaller than that of WIOC (Fig. 8), and WSOC concentration was not reported. The major difference of this calculation is the higher sulfate fraction $\left([\mathrm{OC}] /\left[\mathrm{nss}-\mathrm{SO}_{4}^{2-}\right] \approx 0.2\right.$ ). At $S S=0.097 \%$, the observed $D_{50}$ was $136 \pm 17 \mathrm{~nm}$, and the calculated $D_{\text {crit }}$ using the data of Mochida et al. (2007) was $142 \mathrm{~nm}$, as summarized in Fig. 11. In the case of other $S S \mathrm{~s}$, $D_{\text {crit }}$ also agrees with the average value of $D_{50}$. This result

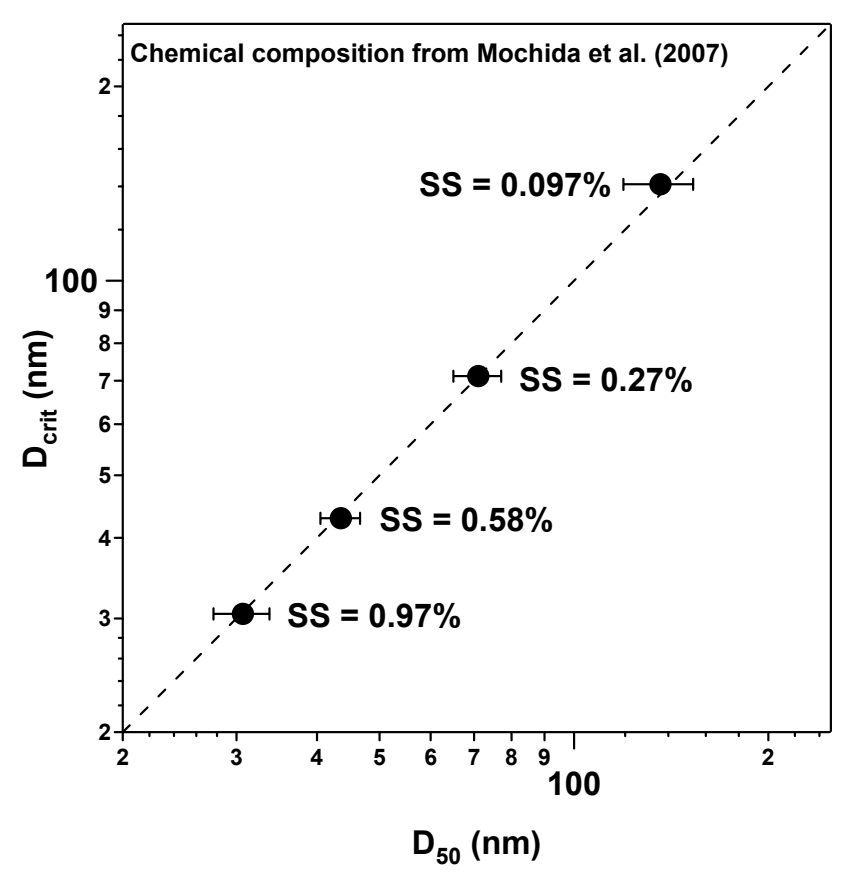

Fig. 11. Comparison of measured $D_{50}$ and $D_{\text {crit }}$ calculated using the chemical composition of Mochida et al. (2007). See the text for detailed explanation.

shows possible effects of the size-dependent chemical composition on $\mathrm{CCN}$ activation.

The size dependence of aerosol chemical composition is clearer for the period of new particle formation. The $D_{50}$ values of newly formed particles were very close to that of ammonium sulfate, indicating that particles were predominantly composed of inorganic compounds at the time (Sect. 4.2.3.). In particular, newly formed particles grew larger than $D_{50}$ at $S S=0.097 \%$ on 31 March (Fig. 4), and $D_{50}$ values were nearly equal to the $D_{\text {crit }}$ of ammonium sulfate on that day (Fig. 9). However, the mass fraction of carbonaceous aerosols (WSOC+WIOC+EC) at $\mathrm{PM}_{2.5}$ was about $30 \%$ at this time (Fig. 8), and this led to the overestimation of $D_{\text {crit }}$ 


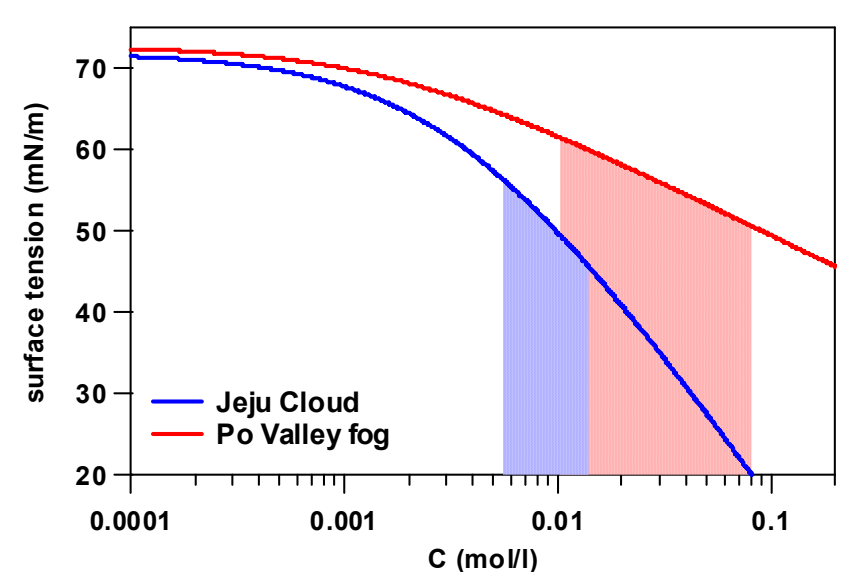

Fig. 12. Decrease of surface tension calculated using the parameters for Jeju cloud water and Po Valley fog by McFiggans et al. (2006). The colored area in the figure corresponds to the values at the critical $S S$ s.

(Fig. 9). The decrease of $D_{50}$ associated with new/secondary particle formation was also observed on 25 March. In this case, the mass fraction of water-insoluble compounds was also $30-40 \%$, and this caused the overestimation of $D_{\text {crit }}$. These results suggest that the $\mathrm{PM}_{2.5}$ mass concentration was biased by large ( $>200-\mathrm{nm}$ ) particles, at least during these periods.

\subsubsection{Decrease of surface tension by organic compounds}

As described above, the surface tension of water was assumed for the calculation in this study. Nevertheless, if the decrease in surface tension due to organic compounds was significant, it may affect the critical $S S$ of the particles (Facchini et al. 1999). Surface tension lowering effects have been observed in various regions of the world such as Po Valley in Italy (Facchini et al. 1999), Mace Head in Ireland (Cavalli et al. 1999), and the Great Hungarian Plain (Kiss et al. 2005. In particular, Decesari et al. (2005) measured the surface tension lowering effect of aerosol, cloud water, and wet deposition samples at Jeju Island during the ACE-Asia campaign. They showed that the decrease of the surface tension due to aerosol was relatively small, whereas the surface tension decrease of cloud water and wet-deposition samples was significant. McFiggans et al. (2006) compared these results, and they showed that the magnitude of the effect for cloud water at Jeju Island was the most significant, and the effects for Po Valley and Mace Head samples were not as large as that of cloud water at Jeju (the red and blue lines in Fig. 12).

They summarized the fitted parameters of the Szyszkowski-Langmuir Eq. (3) obtained for these observation results,

$\sigma=\sigma_{0}-b T \ln (1+a C)$

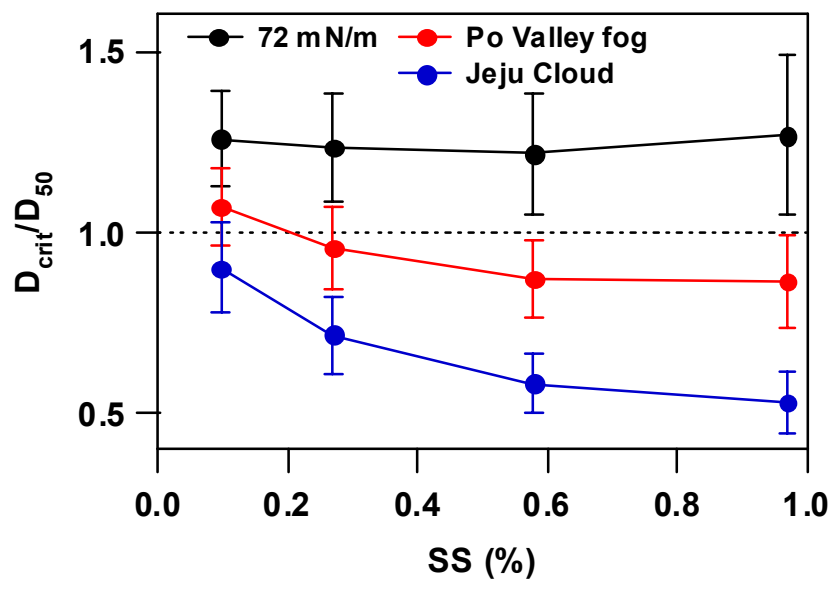

Fig. 13. Comparison of $D_{\text {crit }} / D_{50}$ calculated using several surface tension parameters. The calculation was performed using the adipic acid approximation.

where $\sigma_{0}$ is the surface tension of pure water, $C$ is the WSOC concentration of the solution, and $a$ and $b$ are the empirical parameters obtained by fitting the observational results. In order to investigate the sensitivity of $D_{\text {crit }}$ to surface tension, we calculated $D_{\text {crit }}$ at each $S S$ using the parameters given by McFiggans et al. (2006). In this calculation, the adipic acid assumption was used, and the values for Jeju cloud water and Po Valley fog were employed. Substituting $\sigma$ in Eq. (1) by that expressed by Eq. (3), the $D_{\text {crit }}$ values were obtained by numerical calculation. The results are summarized in Fig. 13. In the case of Jeju cloud water, the calculated diameters for all $S S$ s are smaller than the observed $D_{50}$ by $10-47 \%$, and the use of the equation for Po Valley decreased the differences between $D_{\text {crit }}$ and $D_{50}(7$ to $-13 \%)$. This indicates that the decrease of surface tension can potentially explain the discrepancy. The surface tension at the critical $S S$ was about $46-56 \mathrm{mN} / \mathrm{m}$ (Jeju cloud water) and $51-62 \mathrm{mN} / \mathrm{m}$ (Po Valley), respectively (Fig. 12).

The discussion in this section and Sect. 5.3.1 shows that the size- dependence of chemical composition and the decrease in surface tension are the critical parameters in estimating $D_{\text {crit }}$. For a more quantitative assessment of these effects, we need simultaneous measurements of these parameters and $D_{50}$.

\subsection{Impact of $D_{\text {crit }}$ on CCN number concentration}

The main purpose of the calculation of $D_{\text {crit }}$ is the precise estimation of $\mathrm{CCN}$ number concentration from the particle size distribution. We estimated the difference in CCN number concentration due to the difference in $D_{50}$ and calculated $D_{\text {crit }}$. The following equation was used for the assessment of 
the difference:

$$
\frac{\Delta N_{\mathrm{CCN}}}{N_{\mathrm{CCN}}}=-\frac{\iint_{\log \left(D_{50}\right)}^{\log \left(D_{\text {crit }}\right)}\left(\log D_{p}\right) d \log D_{p}}{N_{\mathrm{CCN}}}
$$

where $N_{\mathrm{CCN}}$ is the number concentration of $\mathrm{CCN}$ measured by the CCN counter, $\Delta N_{\mathrm{CCN}}$ is the difference of the $\mathrm{CCN}$ number concentration caused by the error in the estimation of $D_{\text {crit }}$, and $f_{N}\left(\log D_{p}\right)$ is the number size distribution measured by the SMPS. Therefore, $\Delta N_{\mathrm{CCN}} / N_{\mathrm{CCN}}$ is the ratio of the difference of the $\mathrm{CCN}$ number concentration due to the difference in $D_{\text {crit }}$ and the observed CCN number concentration. $\Delta N_{\mathrm{CCN}} / N_{\mathrm{CCN}}$ depends on the number size distribution $\left(f_{N}\left(\log D_{p}\right)\right)$ and the uncertainty of the chemical composition $\left(D_{\text {crit }}-D_{50}\right)$. For this calculation, the calculated $D_{\text {crit }}$ (adipic acid assumption, surface tension of water) was used. In addition to the adipic acid assumption, we also calculated $\Delta N_{\mathrm{CCN}} / N_{\mathrm{CCN}}$ using the ammonium sulfate assumption ( $D_{\text {crit }}=D_{\text {crit }}$ of ammonium sulfate) because this assumption has frequently been used in previous CCN studies (e.g. VanReken et al., 2003), including those for Gosan (Yum et al., 2007). The results are summarized in Fig. 14. In general, the adipic acid approximation underestimates the $\mathrm{CCN}$ number concentration due to the overestimation of $D_{\text {crit }}$, whereas the ammonium sulfate approximation overestimates the $\mathrm{CCN}$ number concentration because of the underestimation of the $D_{\text {crit. }}$ At $S S=0.097 \%, \Delta N_{\mathrm{CCN}} / N_{\mathrm{CCN}}$ was $-0.27 \pm 0.14$ and $0.16 \pm 0.18$ for the adipic acid and ammonium sulfate approximations, respectively. These values give a measure of the uncertainty associated with the $\mathrm{CCN}$ prediction based on the results of this study. The absolute value of $\Delta N_{\mathrm{CCN}} / N_{\mathrm{CCN}}$ increased with decreasing $S S$. During the observation period, the average values of $B$ did not show a significant dependence on the value of $S S$ as discussed in Sect. 4.2.2, and the magnitude of the error associated with the estimation of $D_{\text {crit }}$ did not depend on $S S$ significantly. Thus, this trend was not mainly due to the size dependence of the chemical composition. $D_{\text {crit }}$ decreased with increasing $S S$. The particle number concentration between $D_{50}$ and $D_{\text {crit }}$ was smaller at higher $S S$ in comparison with the $\mathrm{CCN}$ number concentration because at higher $S S$ a larger fraction of $\mathrm{CCN}$ is in the size range larger than $D_{50}$, as can be seen from Fig. 6 . These results show that the effect of chemical composition on $N_{\mathrm{CCN}}$ was more important at lower $S S$, and the aerosol number size distribution was important at higher $S S$.

\section{Summary}

We measured the $\mathrm{CCN}$ number concentration $\left(N_{\mathrm{CCN}}\right)$ and the size-resolved $\mathrm{CCN} / \mathrm{CN}$ ratios at $S S=0.097,0.27,0.58$, and $0.97 \%$ on Jeju Island, Korea, during 18 March-5 April 2005. The average CCN number concentrations for the whole observational period were as high as $1194 \pm 746 \mathrm{~cm}^{-3}$

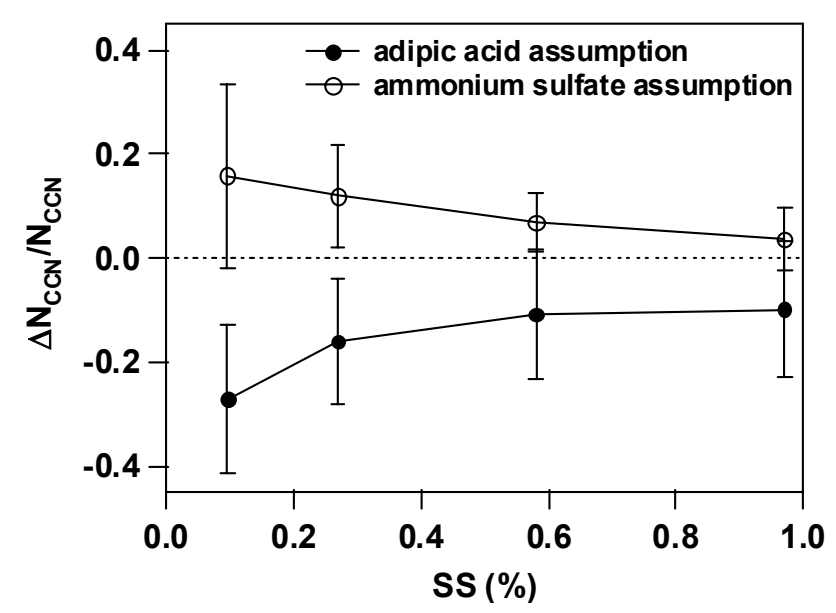

Fig. 14. Average values and standard deviations of $\Delta N_{\mathrm{CCN}} / N_{\mathrm{CCN}}$.

$(S S=0.097 \%)$ and $3966 \pm 1686 \mathrm{~cm}^{-3} \quad(S S=0.97 \%)$. The $\mathrm{CCN} / \mathrm{CN}$ ratios monotonically increased with increasing particle diameter, and the diameter at $\mathrm{CCN} / \mathrm{CN}=0.5$ was defined as $D_{50}$. The average $D_{50}$ values at $S S=0.097 \%$ and $0.97 \%$ were $136 \mathrm{~nm}$ and $31 \mathrm{~nm}$, respectively. These values were slightly larger than those of ammonium sulfate particles (125 and $27 \mathrm{~nm}$ at $S S=0.097 \%$ and $0.97 \%$, respectively). In particular, $D_{50}$ diameters of newly formed particles and those of ammonium sulfate particles were almost identical for $S S=0.97,0.58$ and $0.27 \%$, indicating that these particles were mainly composed of ammonium sulfate. The peak diameter of the CCN size distribution averaged for the whole observational period was about $150 \mathrm{~nm}$ at $S S=0.097 \%$ and shifted to about $80 \mathrm{~nm}$ at $S S=0.97 \%$.

The temporal variation of $D_{50}$ at $S S=0.097 \%$ was negatively correlated with the variation of the water-soluble fraction (inorganics + WSOC) of the aerosol components. For quantitative comparison, the threshold diameters for CCN activation $\left(D_{\text {crit }}\right)$ were calculated by Köhler theory assuming the surface tension of water and $\mathrm{PM}_{2.5}$ aerosol chemical composition. The calculated $D_{\text {crit }}$ values were correlated with $D_{50}$ at $S S=0.097 \%\left(r^{2}=0.48\right)$. However, $D_{\text {crit }}$ was systematically larger than $D_{50}$ by about $16-29 \%$. Sensitivity studies have shown that this discrepancy can be explained by possible differences in aerosol chemical composition between the sub-micron and super-micron size ranges. In addition, a decrease of the surface tension due to the existence of WSOC can also significantly decrease $D_{\text {crit }}$.

The particle number concentrations in the size range between $D_{50}$ and $D_{\text {crit }}\left(\Delta N_{\mathrm{CCN}}\right)$ were calculated using the observed size distribution. The ratios of $\Delta N_{\mathrm{CCN}}$ to $N_{\mathrm{CCN}}$ $\left(\Delta N_{\mathrm{CCN}} / N_{\mathrm{CCN}}\right)$ were estimated to be $-0.27 \pm 0.14$ and $-0.10 \pm 0.13$ at $S S=0.097 \%$ and $0.97 \%$, respectively, assuming that water-soluble organic compounds are represented by adipic acid. The $\Delta N_{\mathrm{CCN}} / N_{\mathrm{CCN}}$ ratio gives a measure of the uncertainty in estimating $\mathrm{CCN}$ number concentrations using 
particle number size distributions and $\mathrm{PM}_{2.5}$ chemical compositions in the East Asia region.

Acknowledgements. We acknowledge anonymous reviewers for their useful comments. We also thank C. S. Hong and Y. J. Kim for their support of the observations. This work was supported by the Ministry of Education, Culture, Sports, Science, and Technology (MEXT), the Japanese Science and Technology Agency (JST), and the global environment research fund of the Japanese Ministry of the Environment. M. Kuwata thanks the Japan Society for the Promotion of Science (JSPS) for a JSPS Research Fellowship for Young Scientists. J. H. Kim and S. S. Yum were supported by the Korean Ministry of Environment under the "Eco-techonopia 21 project".

Edited by: C. Chan

\section{References}

Akimoto, H.: Global air quality and pollution, Science, 302, 17161719, 2003.

Arnold, F.: Atmospheric aerosol and cloud condensation nuclei formation: A possible influence of cosmic rays?, Space. Sci. Reviews, 125, 169-186, 2006.

Bae, M.-S., Schauer, J. J., DeMinter, J. T., Turner, J. R., Smith D., and Cary, R. A.: Validation of a semi-continuous instrument for elemental carbon and organic carbon using a thermal-optical method, Atmos. Environ., 38, 2885-2893, 2004.

Buzorius, G., McNaughton, C. S., Clarke, A. D., Covert, D. S., Blomquist, B., Nielsen, K., and Brechtel, F. J.: Secondary aerosol formation in continental outflow conditions during ACE-Asia, J. Geophys. Res., 109, D24203, doi:10.1029/2004JD004749, 2004.

Cantrell, W., Shaw, G., Cass, G. R., Chowdhury, Z., Hughes, L. S., Prather, K. A., Guazzotti, S. A., and Coffee, K. R.: Closure between aerosol particles and cloud condensation nuclei at Kaashidhoo Climate Observatory, J. Geophys. Res., 106(D22), 28 711-28 718, 2001.

Carmichael, G. R., Hong, M., Ueda, H., Chen, L., Murano, K., Park, J. K., Lee, H., Kim, Y., Kang, C., and Shim, S.: Aerosol composition at Cheju Island, Korea, J. Geophys. Res., 102(D5), 6047-6062, 1997.

Cavalli, F., Facchini, M. C., Decesari, S., et al.: Advances in characterization of size-resolved organic matter in marine aerosol over the North Atlantic, J. Geophys. Res., 109, D24215, doi:10.1029/2004JD005137, 2004.

Chameides, W. L., Luo, C., Saylor, R., Streets, D. G., Huang, Y., Bergin, M., and Giorgi, F.: Correlation between modelcalculated anthropogenic aerosols and satellite-derived cloud optical depths: Indication of indirect effect?, J. Geophys. Res., 107(D10), 4085, doi:10.1029/2000JD000208, 2002.

Clegg, S. L., Rard, J. A., and Pitzer, K. S.: Thermodynamic properties of $0-6 \mathrm{~mol} \mathrm{Kg}-1$ aqueous sulfuric acid from $273.15 \mathrm{~K}$ to 328.15K, J. Chem. Soc. Faraday Trans., 90, 1875-1894, 1994.

Clegg, S. L., Milioto S., and Palmer, D. A.: Osmotic and activity coefficients of aqueous $\left(\mathrm{NH}_{4}\right)_{2} \mathrm{SO}_{4}$ as a function of temperature, and $\left(\mathrm{NH}_{4}\right)_{2} \mathrm{SO}_{4}-\mathrm{H}_{2} \mathrm{SO}_{4}$ mixtures at $298.15 \mathrm{~K}$ and $323.15 \mathrm{~K}$, J. Chem. Eng. Data, 41, 455-467, 1996.
Corrigan, C. E. and Novakov, T.: Cloud condensation nucleus activity of organic compounds: A laboratory study, Atmos. Environ., 33, 2661-2668, 1999.

Covert, D. S., Gras, J. L., Wiedensohler A., and Stratmann, F.: Comparison of directly measured $\mathrm{CCN}$ with $\mathrm{CCN}$ modeled from the number-size distribution in the marine boundary layer during ACE 1 at Cape Grim, Tasmania, J. Geophys. Res., 103(D13), 16 597-16 608, 1998.

Cruz, C. N. and Pandis, S. N.: Deliquescence and hygroscopic growth of mixed inorganic-organic atmospheric aerosol, Environ. Sci. Technol., 34, 4313-4319, 2000.

Decesari, S., Facchini, M. C., Fuzzi, S., McFiggans, G. B., Coe, H., and Bower, K. N.: The water-soluble organic component of sizesegregated aerosol, cloud water and wet depositions from Jeju Island during ACE-Asia, Atmos. Environ., 39, 211-222, 2005.

Dinar, E., Taraniuk, I., Graber, E. R., Katsman, S., Moise, T., Anttila, T., Mentel, T. F., and Rudich, Y.: Cloud Condensation Nuclei properties of model and atmospheric HULIS, Atmos. Chem. Phys., 6, 2465-2481, 2006a,

http://www.atmos-chem-phys.net/6/2465/2006/.

Dinar, E., Mentel, T. F., and Rudich, Y.: The density of humic acids and humic like substances (HULIS) from fresh and aged wood burning and pollution aerosol particles, Atmos. Chem. Phys., 6, 5213-5224, 2006b, http://www.atmos-chem-phys.net/6/5213/2006/.

Dusek, U., Frank, G. P., Hildebrandt, L., Curtius, J., Schneider, J., Walter, S., Chand, D., Drewnick, F., Hings, S., Jung, D., Borrmann, S., and Andreae, M. O.: Size matters more than chemistry for cloud-nucleating ability of aerosol particles, Science, 312, 1375-1378, 2006.

Facchini, M. C., Mircea, M., Fuzzi, S., and Charlson, R. J.: Cloud albedo enhancement by surface-active organic solutes in growing droplets, Nature, 401, 257-259, 1999.

Grabber, E. R. and Rudich Y: Atmospheric HULIS: How humic-like are they? A comprehensive and critical review, Atmos. Chem. Phys., 6, 729-753, 2006, http://www.atmos-chem-phys.net/6/729/2006/.

Hoffer, A., Gelencsèr, A., Guyon, P., Kiss, G.., Schmid, O., Frank, G. P., Artaxo, P., and Andrea, M. O.: Optical properties of humiclike substances (HULIS) in biomass-burning aerosols, Atmos. Chem. Phys., 6, 3563-3570, 2006, http://www.atmos-chem-phys.net/6/3563/2006/.

Hudson, J. G. and Yum, S. S.: Cloud condensation nuclei spectra and polluted and clean clouds over the Indian Ocean, J. Geophys. Res., 107(D19), 8022, doi:10.1029/2001JD000829, 2002.

Huff Hartz, K. F., Tischuk, J. E., Chan, M. N., Chan, C. K., Donahue, N. M., and Pandis, S. N.: Cloud condensation nuclei activation of limited solubility organic aerosol, Atmos. Environ., 40, 605-617, 2006.

Kawamoto, K., Hayasaka, T., Uno, I., and Ohara, T.: A correlative study on the relationship between modeled anthropogenic aerosol concentration and satellite-observed cloud properties over east Asia, J. Geophys. Res., 111, D19201, doi:10.1029/2005JD006919, 2006.

Kawamura, K., Umemoto, N., Mochida, M., Bertram, T., Howell, S., and Huebert, B. J.: Water-soluble dicarboxylic acids in the tropospheric aerosols collected over east Asia and western North Pacific by ACE-Asia C-130 aircraft, J. Geophys. Res., 108(D23), 8639, doi:10.1029/2002JD003256, 2003. 
Kim, J., Yoon, S.-C., Jefferson, A., and Kim, S.-W.: Aerosol hygroscopic properties during Asian dust pollution, and biomass burning episodes at Gosan, Korea in April 2001, Atmos. Environ., 40, 1550-1560, 2006.

Kiss, G., Tombàcz, E., and Hanson, H.-C.: Surface tension effects of Humic-like substances in the aqueous extract of tropospheric fine aerosol, J. Atmos. Chem., 50, 279-294, 2005.

Knutson, E. O. and Whitby, K. T.: Aerosol classification by electric mobility: Apparatus, theory, and applications, J. Aerosol. Sci., 6, 443-451, 1975.

Kondo, Y., Komazaki, Y., Miyazaki, Y., et al.: Temporal variations of elemental carbon in Tokyo, J. Geophys. Res., 111, D12205, doi:10.1029/2005JD006257, 2006.

Kondo, Y., Miyazaki, Y., Takegawa, N., Miyakawa, T., Weber, R. J., Jimenez, J. L., Zhang, Q., and Worsnop, D. R.: Oxygenated and water-soluble organic aerosols in Tokyo, J. Geophys. Res., 112, D01203, doi:10.1029/2006JD007056, 2007.

Kreidenweis, S. M., Koehler, K., DeMott, P. J., Prenni, A. J., Carrico, C., and Ervens, B.: Water activity and activation diameters from hygroscopicity data - Part I: Theory and application to inorganic salts, Atmos. Chem. Phys., 5, 1357-1370, 2005

Kuwata, M., Kondo, Y., Mochida, M., Takegawa, N., and Kawamura, K.: Dependence of CCN activity of less volatile particles on the amount of coating observed in Tokyo, J. Geophys. Res., 112, D11207, doi:10.1029/2006JD007758, 2007.

Laaksonen, A., Hamed, A., Joutsensaari, J., Hiltunen, L., Cavalli, F., Junkermann, W., Asmi, A., Fuzzi, S., and Facchini, M. C.: Cloud condensation nucleus production from nucleation events at a highly polluted region, Geophys. Res. Lett., 32, L06812, doi:10.1029/2004GL022092, 2005.

Lee, J. Y., Kim, Y. P., Kang, C.-H., Ghim, Y. S., and Kaneyasu, N.: Temporal trend and long-range transport of particulate polycyclic aromatic hydrocarbons at Gosan in northeast Asia between 2001 and 2004, J. Geophys. Res., 111, D11303, doi:10.1029/2005JD006537, 2006.

Lohmann, U. and Feichter, J.: Global indirect aerosol effects: A review, Atmos. Chem. Phys., 5, 715-737, 2005, http://www.atmos-chem-phys.net/5/715/2005/.

Markowski, G. R.: Improving Twomey's algorithm for inversion of aerosol measurement data, Aerosol. Sci. Technol., 7, 127-141, 1987.

McFiggans, G.,Artaxo, P., Baltensperger, U., et al.: The effect of physical and chemical aerosol properties on warm cloud droplet activation, Atmos. Chem. Phys., 6, 2593-2649, 2006, http://www.atmos-chem-phys.net/6/2593/2006/.

Matsumoto, K., Tanaka, H., Nagao, I., and Ishizaka, Y.: Contribution of particulate sulfate and organic carbon to cloud condensation nuclei in the marine atmosphere, Geophys. Res. Lett., 24(6), 655-658, 1997.

Medina, J., Nenes, A., Sotiropoulou, R.-E. P., Cottrell, L. D., Ziemba, L. D., Beckman, P. J, and Griffin, R. J.: Cloud condensation nuclei closure during the International Consortium for Atmospheric Research on Transport and Transformation 2004 campaign: Effects of size-resolved composition, J. Geophys. Res., 112, D10S31, doi:10.1029/2006JD007588, 2007.

Miyazaki, Y., Kondo, Y., Takegawa, N., Komazaki, Y., Fukuda, M., Kawamura, K., Mochida, M., Okuzawa, K., and Weber, R. J.: Time-resolved measurements of water-soluble organic carbon in Tokyo, J. Geophys. Res., 111, D23206,
doi:10.1029/2006JD007125, 2006.

Miyazaki, Y., Kondo, Y., Kodama, D., Han, S., Koike, M., Komazaki, Y., Tanimoto, H., and Matsueda, H.: Chemical characteristics of water-soluble organic carbon in the Asian outflow, J. Geophys. Res., 112, D22S30, doi:10.1029/2007JD009116,2007.

Mochida, M., Kawamura, K., Umemoto, N., Kobayashi, M., Matsunaga, S., Lim, H., Turpin, B. J., Bates, T. S., and Simoneit, B. R. T.: Spatial distributions of oxygenated organic compounds (dicarboxylic acids, fatty acids, and levoglucosan) in marine aerosols over the western Pacific and off the coast of East Asia: Continental outflow of organic aerosols during the ACE-Asia campaign, J. Geophys. Res., 108(D23), 8638, doi:10.1029/2002JD003249, 2003.

Mochida, M., Kuwata, M., Miyakawa, T., Takegawa, N., Kawamura, K., and Kondo, Y.: Relationship between hygroscopicity and cloud condensation nuclei activity for urban aerosols in Tokyo, J. Geophys. Res., 111, D23204, doi:10.1029/2005JD006980, 2006.

Mochida, M., Umemoto, N., Kawamura, K., Lim, H.-J., and Turpin, B. J.: Bimodal size distributions of various organic acids and fatty acids in the marine atmosphere: Influence of anthropogenic aerosols, Asian dusts, and sea spray off the coast of East Asia, J. Geophys. Res., 112, D15209, doi:10.1029/2006JD007773, 2007.

O’Dowd, C. D., Hmeri, K., Mkel, J. M., et al.: A dedicated study of New Particle Formation and Fate in the Coastal Environment (PARFORCE): Overview of objectives and achievements, J. Geophys. Res., 107(D19), 8108, doi:10.1029/2001JD000555, 2002.

Orsini, D. A., Ma, Y., Sullivan, A., Sierau, B., Baumann, K., and Weber, R. J.: Refinements to the particle-into-liquid sampler (PILS) for ground and airborne measurements of water soluble aerosol composition, Atmos. Environ., 37, 1243-1259, 2003.

Pang Y., Turpin, B. J., and Gundel, L. A.: On the importance of organic oxygen for understanding organic aerosol particles, Aerosol. Sci . Technol., 40, 128-133, 2006.

Raymond, T. M. and Pandis, S. N.: Cloud activation of single-component organic aerosol particles, J. Geophys. Res., 107(D24), 4787, doi:10.1029/2002JD002159, 2002.

Reade, L., Jennings, S. G., and McSweeney, G.: Cloud condensation nuclei measurements at Mace Head, Ireland, over the period 1994-2002, Atmos. Res., 82, 610-621, 2006.

Richter, A., Burrows, J. P., Nüb, C. Grainer, and Niemeier, U: Increase in tropospheric nitrogen dioxide over China observed from space, Nature, 437, 129-132, 2005.

Roberts, G. C., Artaxo, P., Zhou, J., Swietlicki, E., and Andreae, M. O.: Sensitivity of CCN spectra on chemical and physical properties of aerosol: A case study from the Amazon Basin, J. Geophys. Res., 107(D20), 8070, doi:10.1029/2001JD000583, 2002.

Roberts, G. C. and Nenes, A.: A continuous-flow streamwise thermal gradient $\mathrm{CCN}$ chamber for atmospheric measurements, Aerosol. Sci. Technol., 39, 206-221, 2005.

Sawa, Y., Tanimoto, H., Yonemura, S., Matsueda, H., Wada, A., Taguchi, S., Hayasaka, T., Tsuruta, H., Tohjima, Y., and Mukai, H.: Widespread pollution events of carbon monoxide observed over the western North Pacific during the EAREX 2005 campaign, J. Geophys. Res., 112, D22S26, doi:10.1029/2006JD008055, 2007.

Seinfeld, J. H. and Pandis, S. N.: Atmospheric Chemistry and Physics, John Wiley and Sons, Inc., New York, 2006. 
Simoneit, B. R. T., Kobayashi, M., Mochida, M., Kawamura, K., Lee, M., Lim, H.-J., Turpin, B. J., and Komazaki, Y.: Composition and major sources of organic compounds of aerosol particulate matter sampled during the ACE-Asia campaign, J. Geophys. Res., 109, D19S10, doi:10.1029/2004JD004598, 2004.

Sotiropoulou, R. E. P., Tagaris, E., Pilinis, C., Anttila, T., and Kulmala, M.: Modeling new particle formation during air pollution episodes: Impacts on aerosol and cloud condensation nuclei, Aerosol. Sci . Technol., 40, 557-572, 2006.

Streets, D. G., Tsai, N. Y., Akimoto, H., and Oka, K.: Sulfur dioxide emissions in Asia in the period 1985-1997, Atmos. Environ., 34, 4413-4424, 2000.

Sullivan, A. P., Weber, R. J., Clements, A. L., Turner, J. R., Bae, M. S., and Schauer, J. J.: A method for on-line measurement of water-soluble organic carbon in ambient aerosol particles: Results from an urban site, Geophys. Res. Lett., 31, L13105, doi:10.1029/2004GL019681, 2004.

Takegawa, N., Miyazaki, Y., Kondo, Y., Komazaki, Y., T. Miyakawa, T., Jimenez, J. L., Jayne, J. T., Worsnop, D. R., Allan, J., and Weber, R. J.: Characterization of an Aerodyne Aerosol Mass Spectrometer (AMS): Intercomparison with other aerosol instruments, Aerosol Sci. Technol., 39, 760-770, 2005.

Tanimoto, H., Sawa, Y., Matsueda, H., Wada, A., Yonemura, S., Mukai, H., Wang, T., Poon, S., Wong, A., Lee, G., Jung, J. Y., Kim, K. R., Lee, M. H., Lin, N. H., Wang, J. L., Ou-Yang, C. F, and Wu, C. F.: Evaluation of standards and methods for continuous measurements of carbon monoxide at ground-based sites in Asia, Pap. Met. Geophys., 58, 85-93, doi:10.2467/mripapers.58.85, 2007.
Topping, D., Coe, H., McFiggans, Burgess, G. R., Allan, J., Alfarra, M. R., Bower, K., Choularton, T. W., Decesari, S., and Facchini, M. C.: Aerosol chemical characteristics from sampling conducted on the Island of Jeju Korea during ACE Asia, Atmos. Environ., 38, 2111-2123, 2004.

Twomey, S.: Pollution and the planetary albedo, Atmos. Environ., 8, 1251-1256, 1974.

Van Reken, T. M., Rissman, T. A., Roberts, G. C., Varutbangkul, V., Jonsson, H. H., Flagan, R. C, and Seinfeld, J. H.: Toward aerosol/cloud condensation nuclei $(\mathrm{CCN})$ closure during CRYSTAL-FACE, J. Geophys. Res., 108(D20), 4633, doi:10.1029/2003JD003582, 2003.

Yum, S. S., Hudson, J. G., Song, K. Y., and Choi, B.C.: Springtime cloud condensation nuclei concentrations on the west coast of Korea, Geophys. Res. Lett., 32, L09814, doi:10.1029/2005GL022641, 2005.

Yum, S. S., Roberts, G., Kim, J. H., Song, K., and Kim, D.: Submicron aerosol size distributions and cloud condensation nuclei concentrations measured at Gosan, Korea during the ABC-EAREX 2005, J. Geophys. Res., 112, D22S32, doi:10.1029/2006JD008212., 2007.

Wiedensohler, A.: Technical Note. An Approximation of the bipolar charge distribution for particles in the submicron size range, J. Aerosol. Sci., 19, 387-389, 1988. 